تحليل الأداء الإداري لبعض أدوار العلاقات العامة بالإتحادات الرياضية الأولمبية السعودية

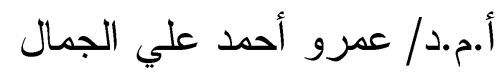

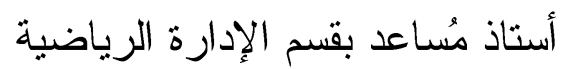

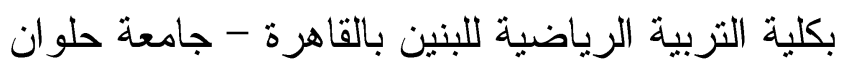

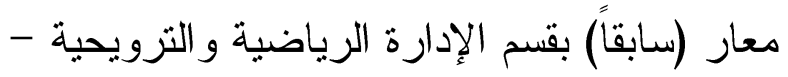

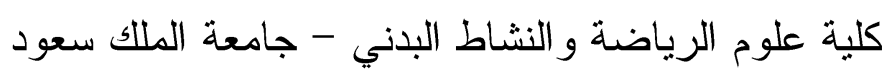

مقدمة البحث :

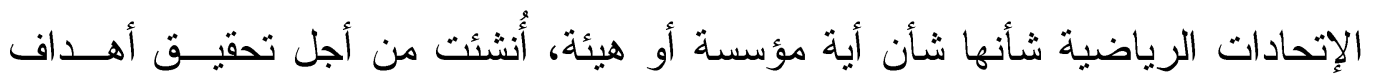

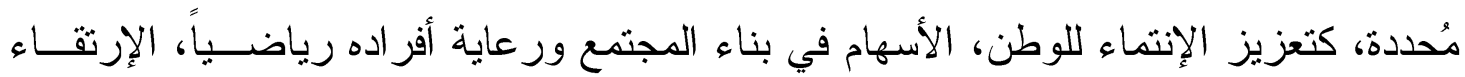

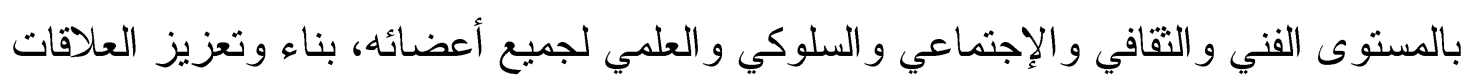

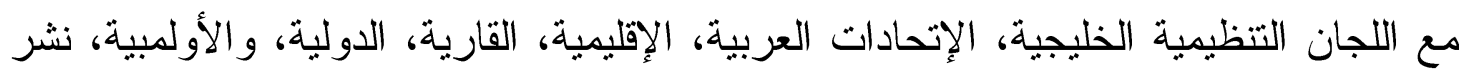

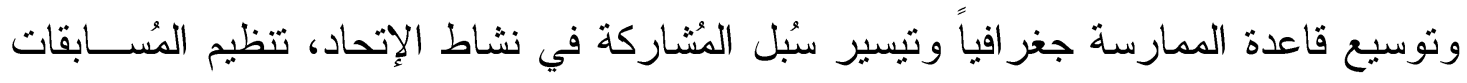

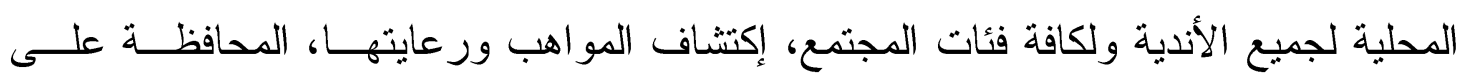

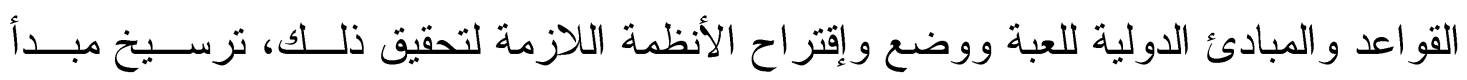
المنافسة الشريفة واللعب النظيف ونبذ التعصب و التمييز، ونشر ثقافة مكافحة المنشطات بـين ولين الممارسين. (اللجنة الأولمبية السعودية، 2017)

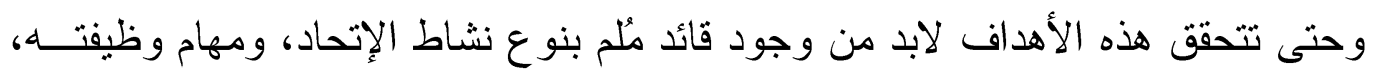

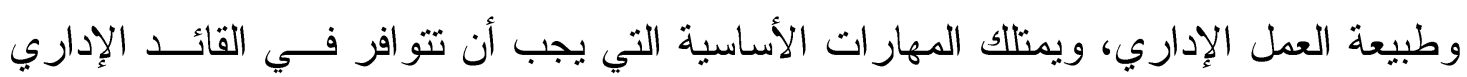

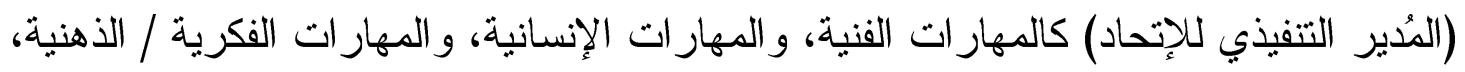

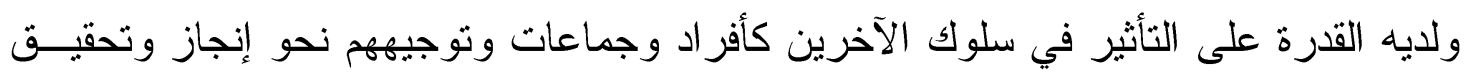

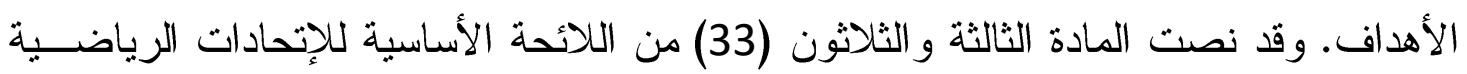

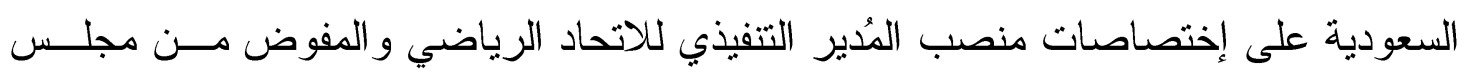

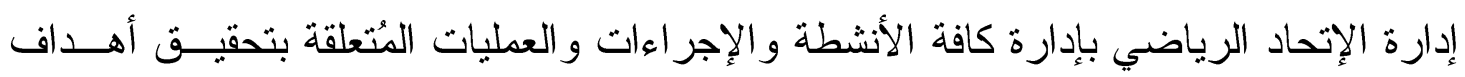

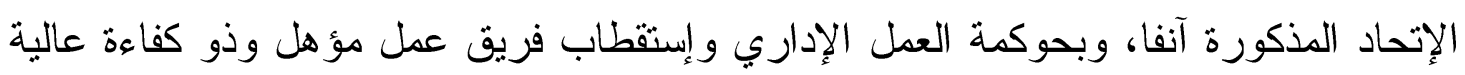

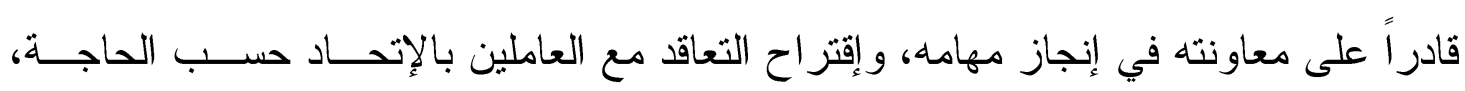

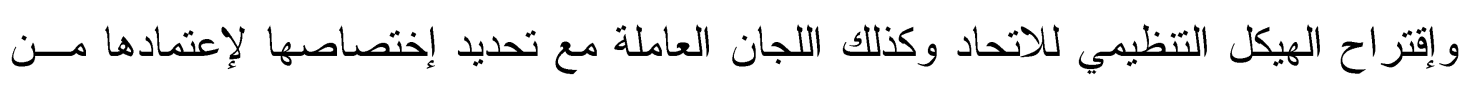

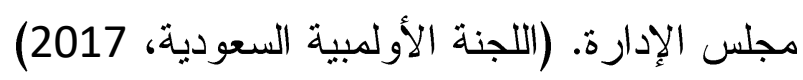

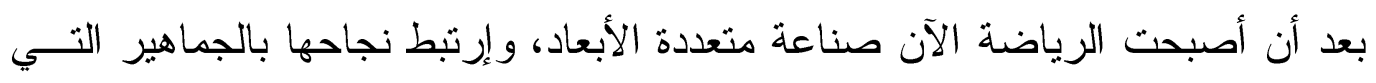

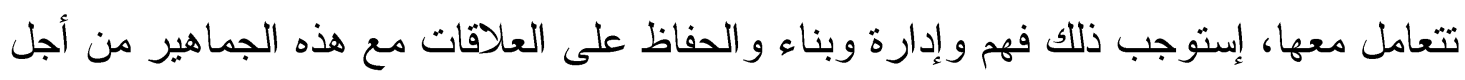


تحقيق النجاح لهيئاتهم الرياضية. لذلك إزدادت الحاجة إلى وظيفة إدارية مميزة تســاعد فــي إنشاء و الحفاظ على قنو ات إتصال متبادلة وتحقيق التفاهم و القبول و الرضا و التعاون بين الهيئة

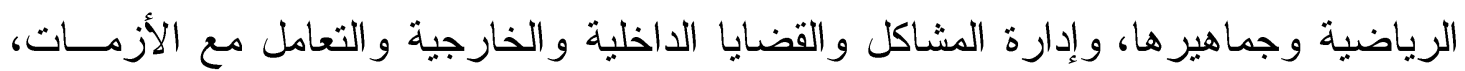

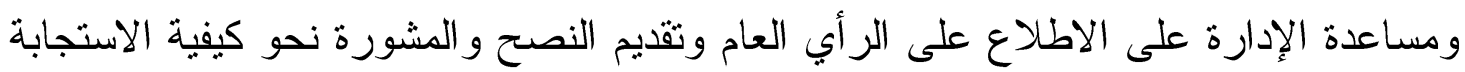

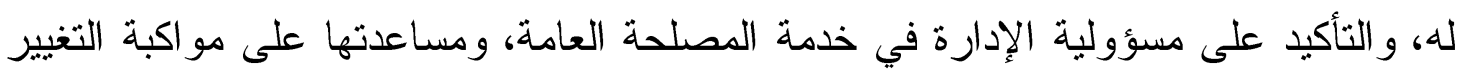

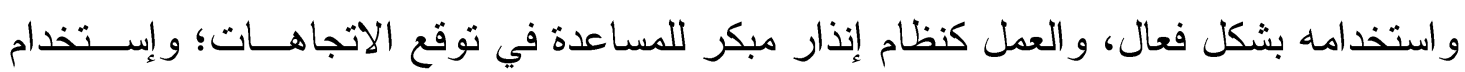
البحث العلمي وتقنيات الاتصال الأخلاقي السليمة كأدوات رئيسية فـــي ممارســــة وظائفهــا. Wilcox, et al., 2007, Summers \& Morgan, 2008, L'Etang, 2006, ) Hopwood, Kitchin, \& Skinner, 2010, L'Etang, 2013a, Pratt, 2013, Mullin,

(Hardy, \& Sutton, 2014

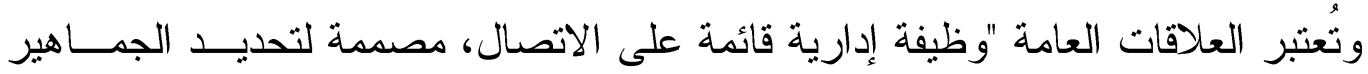

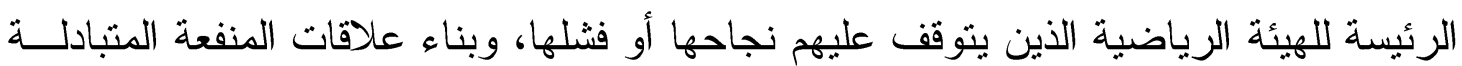
معهم وتقييم هذه العلاقات بصفة مُستمرة، لتعزيز العلاقات المرغوبة [الإســتراتيجية الهامــة]

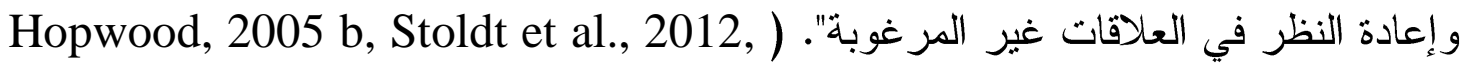

(Broom \& Sha, 2013

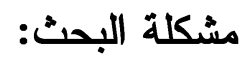

خلص العلماء في مجال الإدارة الرياضية إلى أن العلاقات العامة في المجال الرياضــي

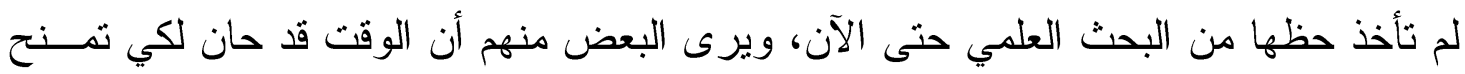

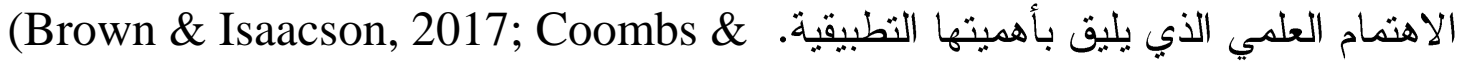
2005 b; Isaacson, 2010; L'Etang, 2006, 2013a, Osborne, 2012; Hopwood, 2015; L'Etang \& Hopwood, 2008).

وقد إتفق العديد من الباحثين في مجال العلاقات العامة الرياضية على أن البحوث العلمية

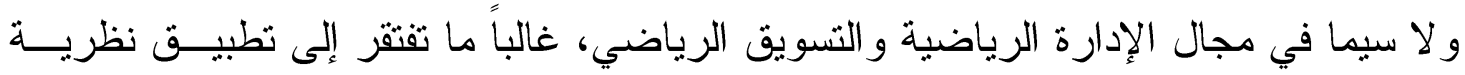

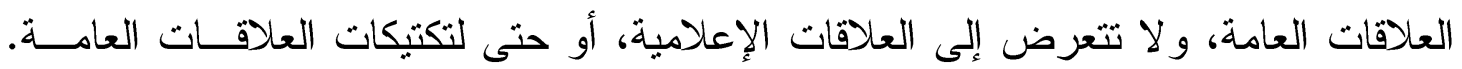

(Brown \& Isaacson, 2017, L’Etang, 2006, 2013a, Waters, 2013)

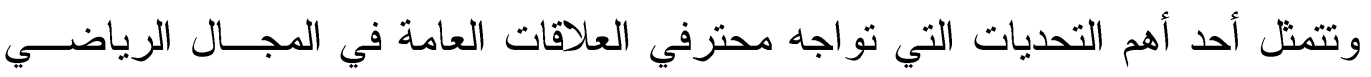
و غير هم من مديري الهيئات الرياضية في [تحليل] وتقييم فعالية وظيفة العلاقات العامة داخـلـل

مؤسساتهر. (Stoldt, 2008; Stoldt, Dittmore, \& Branvold, 2006) كما توصلت العديد من بحوث العلاقات العامة إلى أن وجود نظام منضــبط للعلاقــات العامة يمكن أن يُقام قيمة أكبر للهيئات الرياضية إذا ما تم استخدامه بشكل استر اتيجي و لأكثر 
من مجرد توصيل الرسائل إلى الجمهور • ويُشير استخدام مصطلح (إستر اتيجي) إلــى وجــود خطة مدروسة لتحقيق الأهداف و الغايات التنظيمية، وبالتالي المساهمة في الإدارة الإستر اتيجية التئية

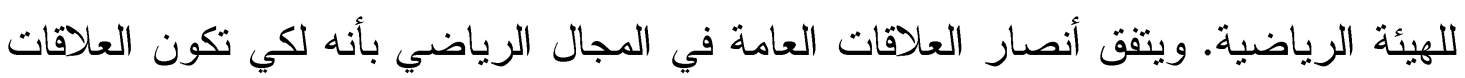

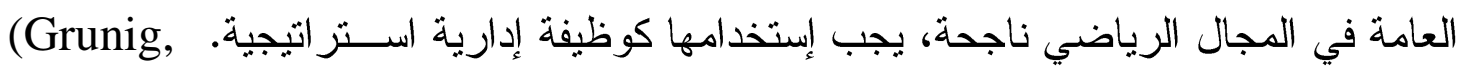
2006, Coombs \& Holladay, 2010, Hopwood et al., 2010; L'Etang, 2013a;

Stoldt et al., 2012)

ويتفق الباحث مع Hon (1997، 1998)، على أن العلاقات العامة تُصبح فعالة عنـــما

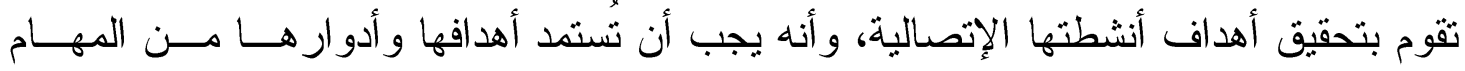

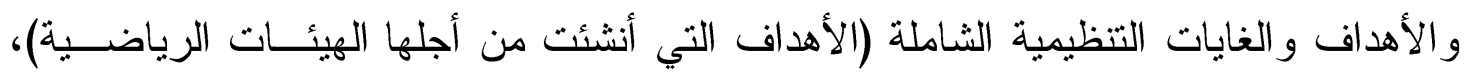

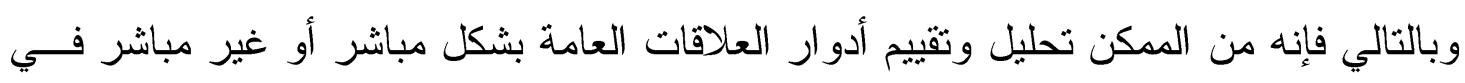

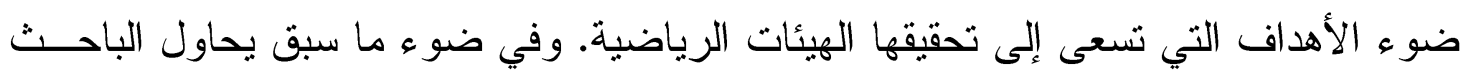

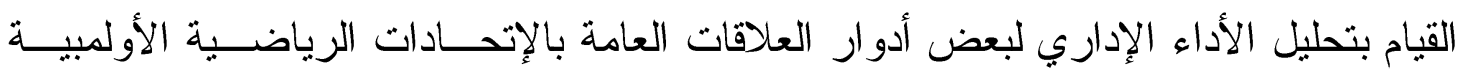

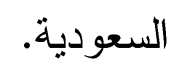

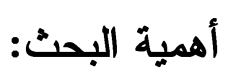

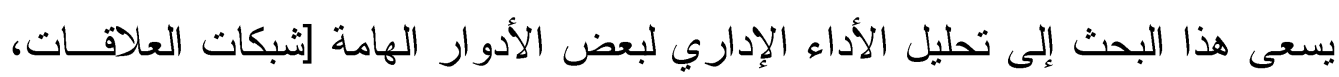

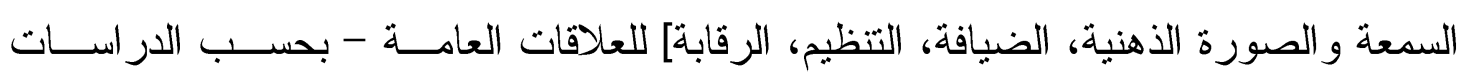

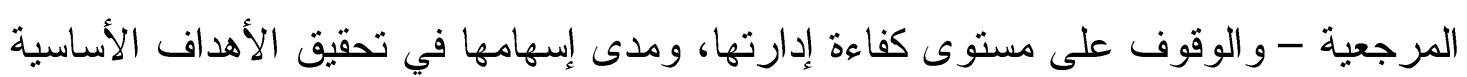

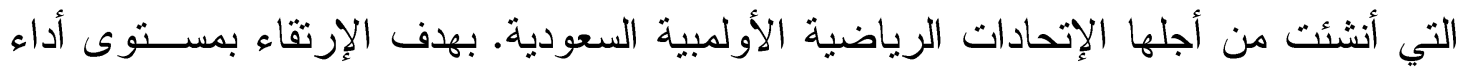

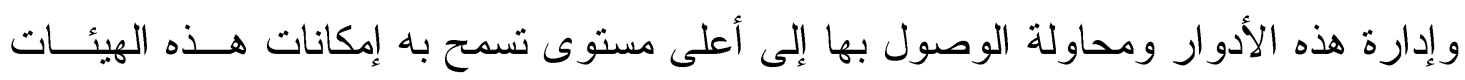
الرياضية الحيوية.

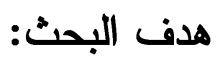

تحليل الأداء الإداري لبعض أدوار العلاقات العامة بالإتحادات الرياضـــية الأولمبيـــة

$$
\text { تساؤ لات البحث: }
$$

التساؤل الأول: ما و اقع الأداء الإداري لثبكات العلاقات العامة فــي الإتحـــادات الرياضـــية

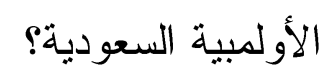

التساؤل الثاني: ما و اقع الأداء الإداري للسمعة و الصـــورة الذهنيــة للإتحــــادات الرياضـــية

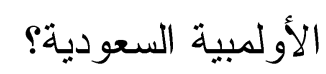

التساؤل الثالث: ما و اقع الأداء الإداري لشئون الضيافة في الإتحادات الرياضـــية الأولمبيــة السعودية؟ 
التساؤل الرابع: ما و اقع الأداء الإداري في تتظـــم شـــون العلاقــات العامــة بالإتحــادات

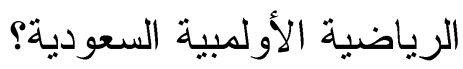

التساؤل الخامس: ما و اقع الأداء الإداري في تقويم أداء (أدوار) العلاقات العامة في الإتحادات

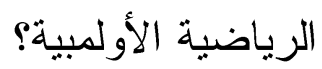

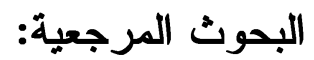

1-توصل Çelebi (2021) إلى أنه من المفيد أن تكون هناك رقابة منبادلــة بـين الهيئــة

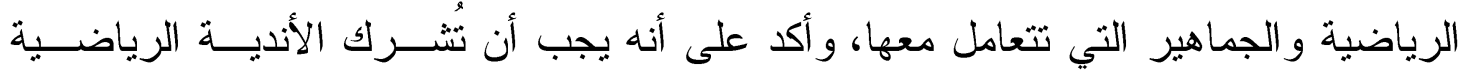

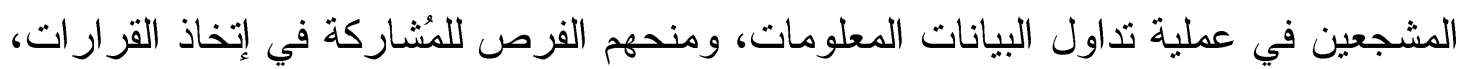

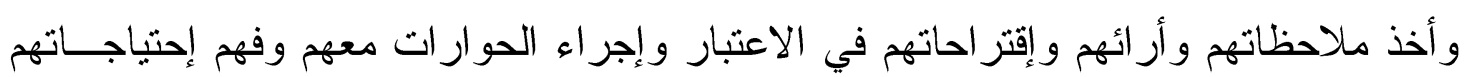
و إهتماماتهم و العمل على تلبيتها، وتطوير إستر اتيجيات جديدة وفعالة تشـتهدف زيــادة عـدـد

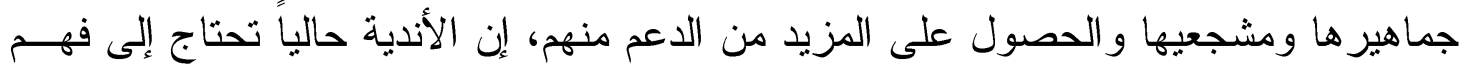

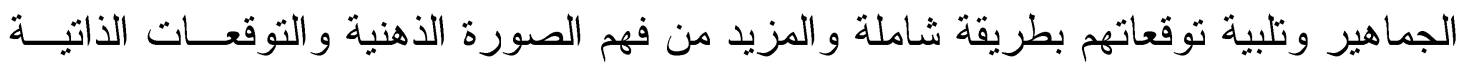

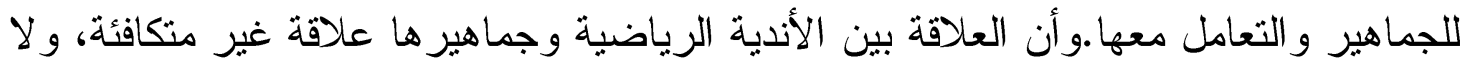

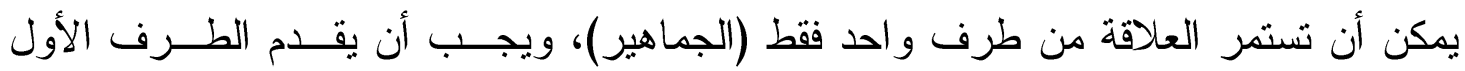

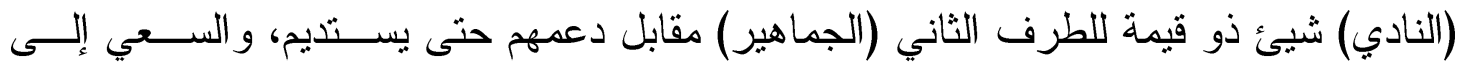
التو اصل معهم، وتحفيز هم وتحقيق رضاهم. وأن النادي يقع على عاثقه مسئولية إجتماعية تجاه

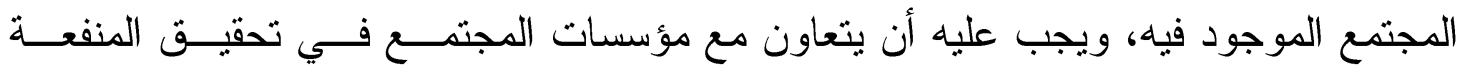

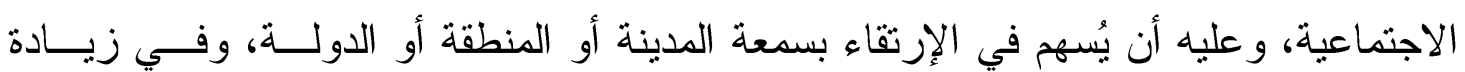

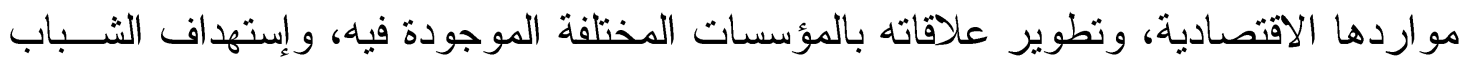

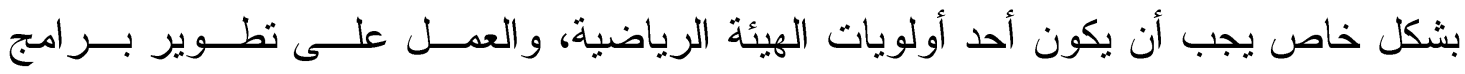
وفعاليات و أنشطة عالية الجودة موجهة للشباب من أجل إستثمار وشغل أوقات فر اغهم، وزيادة مُشاركاتهم الاجتماعية، وو لائهم و إنتمائهم للوطن. 2- توصلت الحجرف (2020)، إلى أن المفهوم الحالي للعلاقات العامة بهذه العيئات الرياضية لهئه

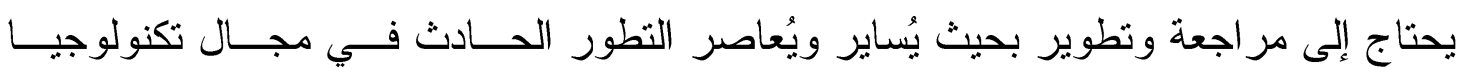

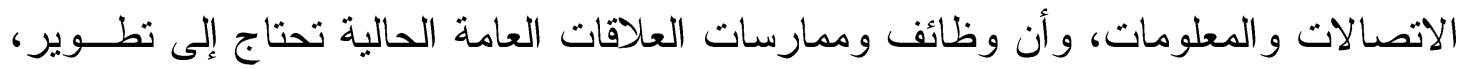

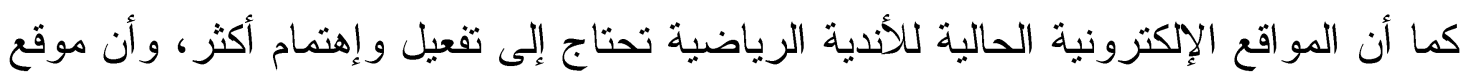

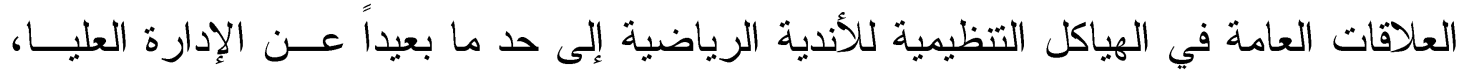

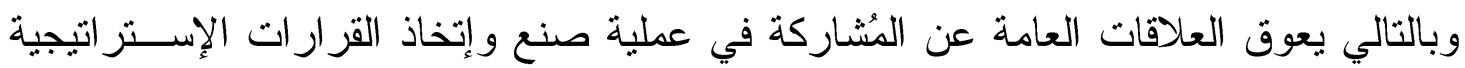

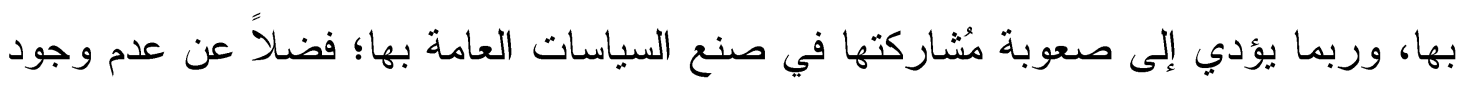


إختصاصات واضحة للعلاقات العامة بالأندية الرياضية، وأحياناً ينم تكليفها القبام بأعمال ليست

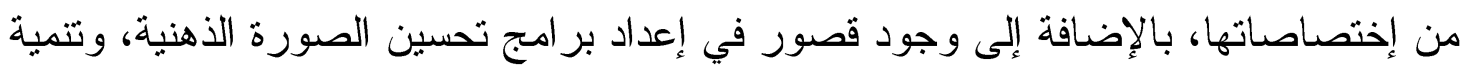
الثعور بالفخر والإنتماء والإعتز از و الو لاء لهذه الأندية الرياضية. 3- نوصل بحث Stevens (2018)، إلى أن الهيئات الرياضية الوطنية تعتبر العلاقات العامة

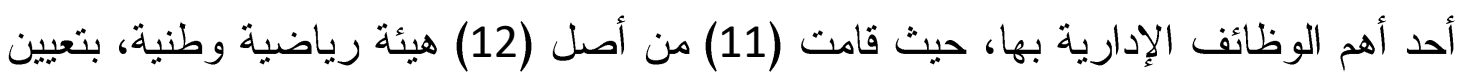

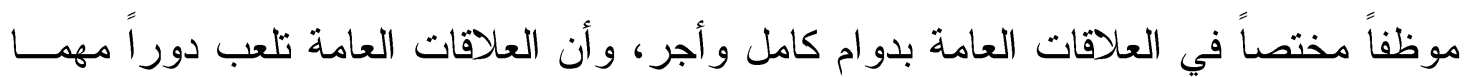

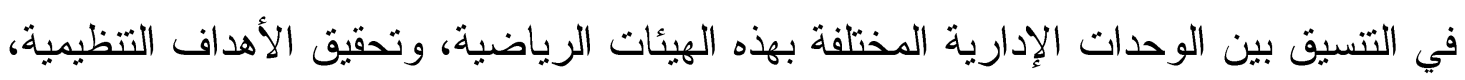

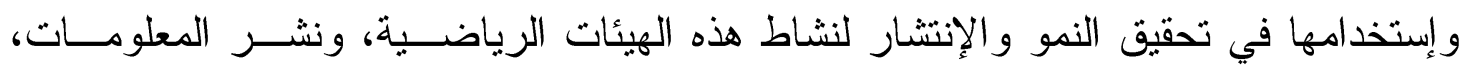

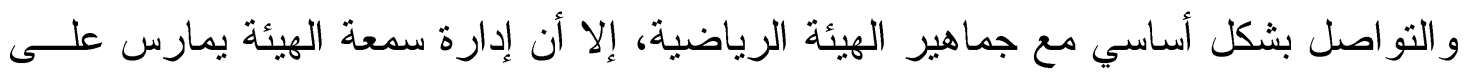

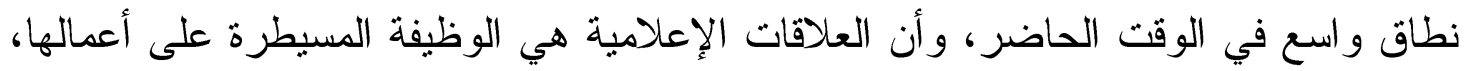

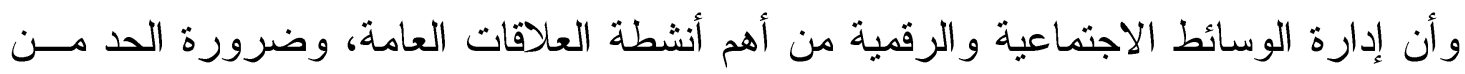

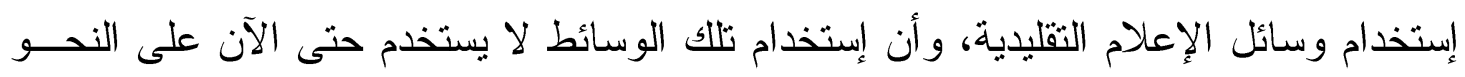

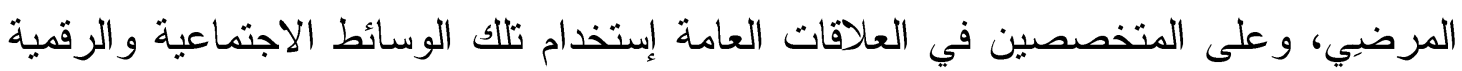

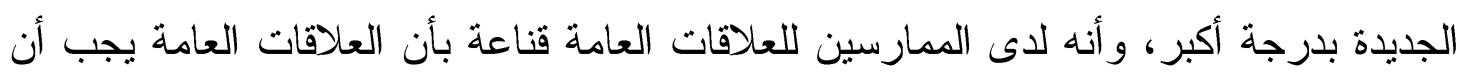

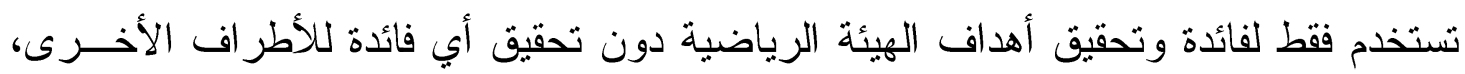

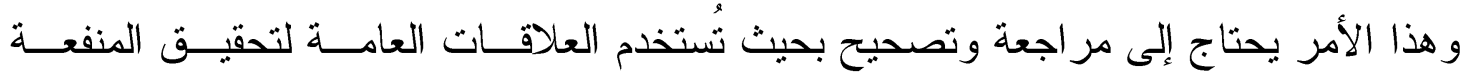

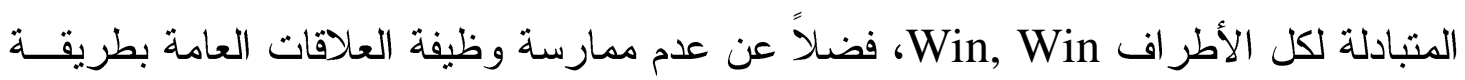

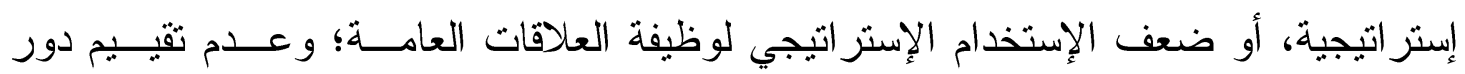

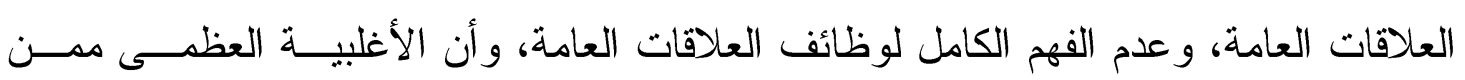

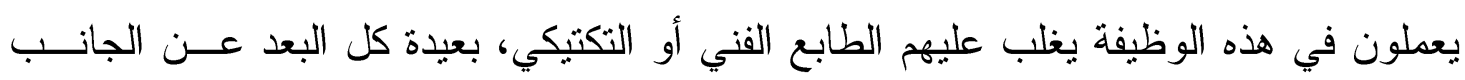

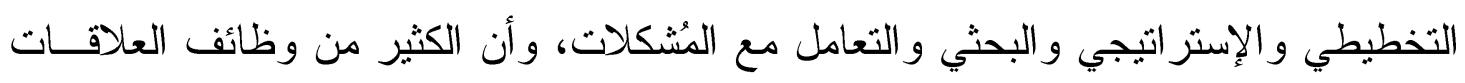

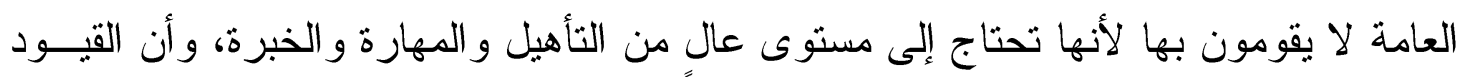

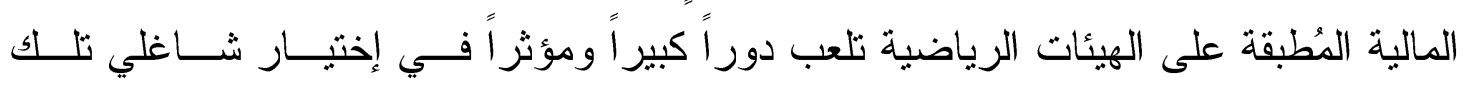

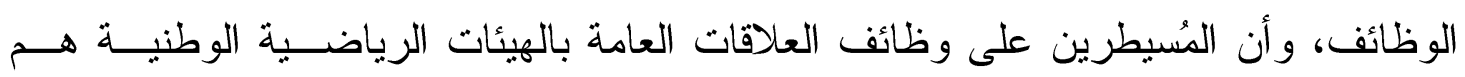

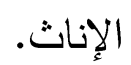

4- توصل العتيبي (2017)، أن أغلبية العاملين في وظائف العلاقات العامة بالأندية الرياضية

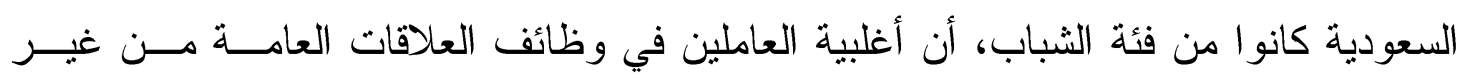

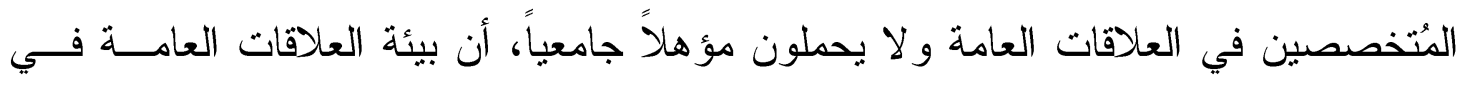

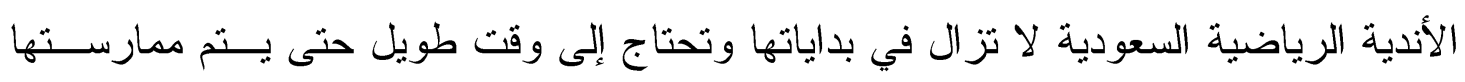


بطريقة علمية إحتر افية، ينراوح عدد العاملين في إدارات العلاقات العامة بالأندية الرياضــية

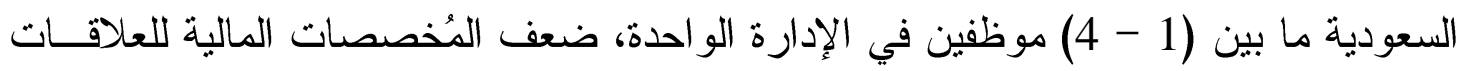

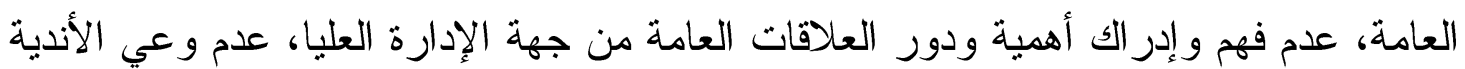
الرياضية بالدور الكامل للعلاقات العامة فيها، كانت أهم الأدوار التي لعبتها العلاقات الإدات العامة في

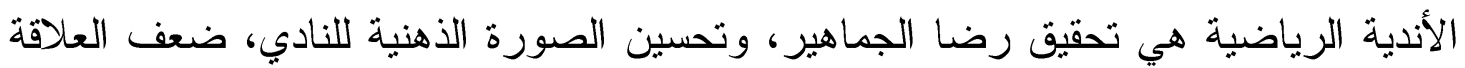

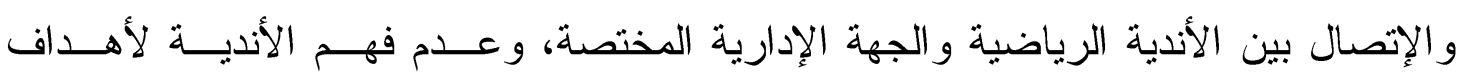

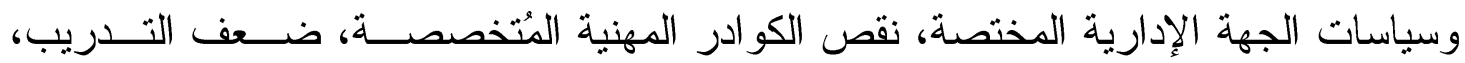

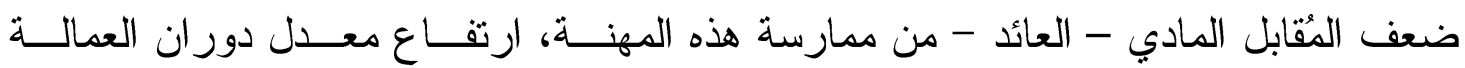
بالعلاقات العامة في الأندية الرياضية السعودية. 5- توصل Wojciechowski (2017)، إلى أن حوالي خمسين بالمائة (50\%) من الهيئات

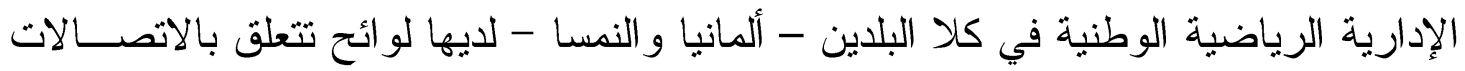

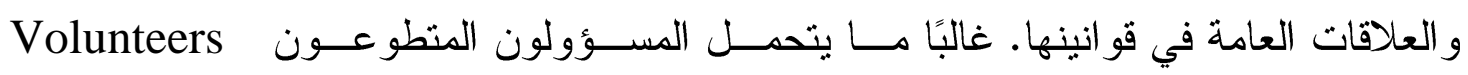
Officials بعبار ات مختلفة في القو انين: يؤكد البعض بوضوح عهو على المصطلحات التقليدية مثل "المتحدث الرسمي" Spokesperson، يبدو أن البعض الآخر أكثر حداثة مثل "موظف العلاقات العامة" Head of Department Public Relations Officer Communications

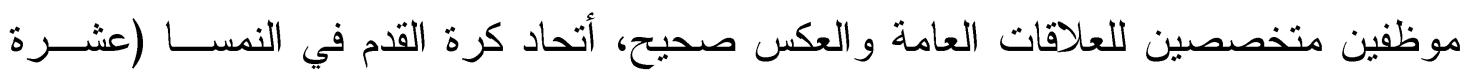

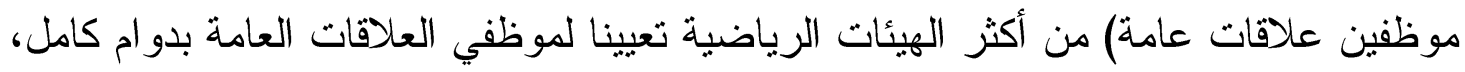

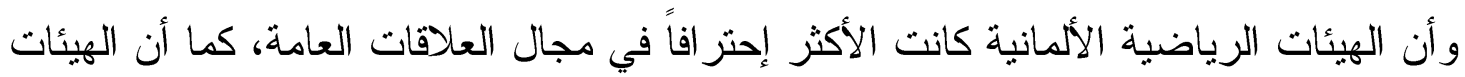

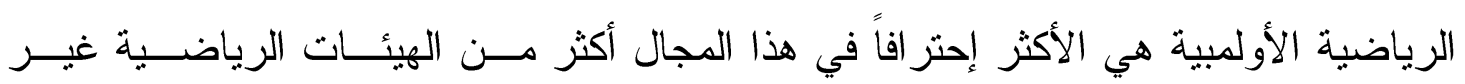
الأولمبية.

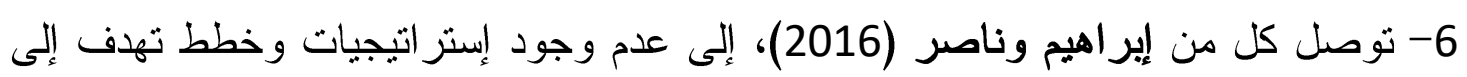

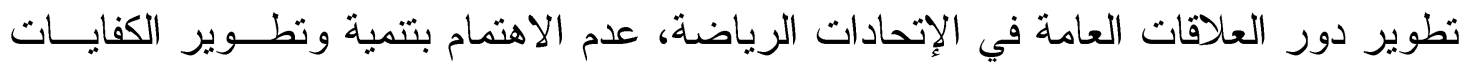

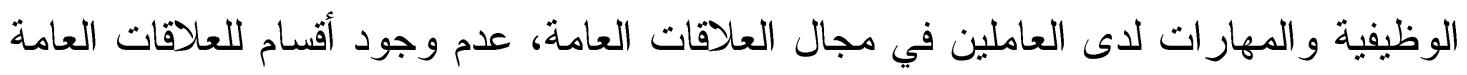

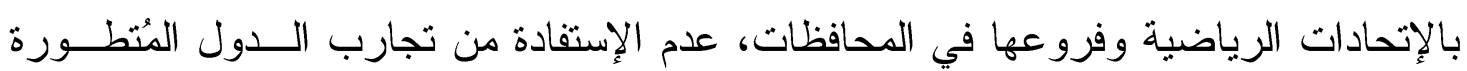

$$
\text { و الخبر اء في مجال العلاقات العامة. }
$$

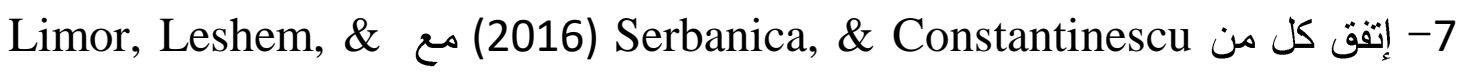
Mendelzis 
و المتبر عين وتنظيم رو ابط ونو ادي المُشجعين و الحفاظ على التو اصل معهم؛ و العمل مع وسائل

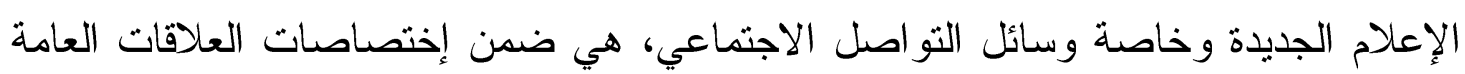
بالهيئات الرياضية. 8- قام Limor, Leshem, \& Mendelzis (2013)، بتحديد ما لا يقل عن (17) جانبًا أو

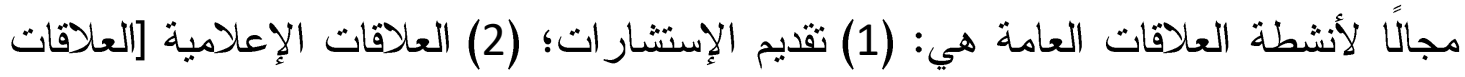

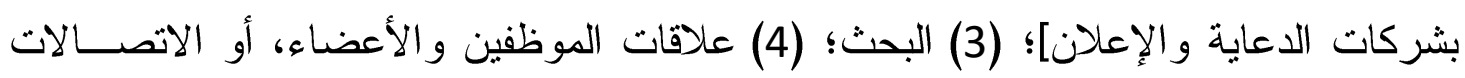

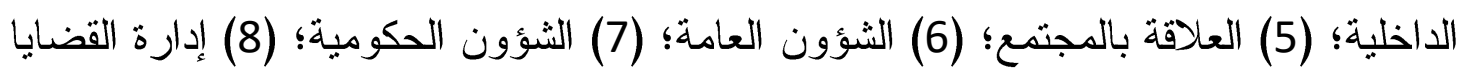

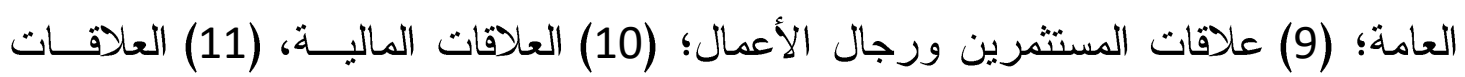

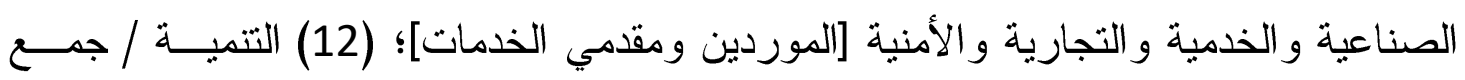

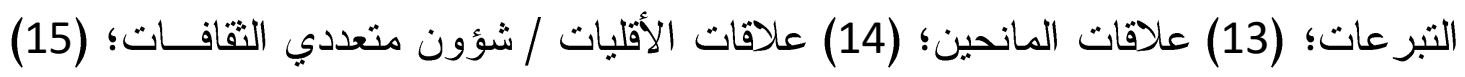

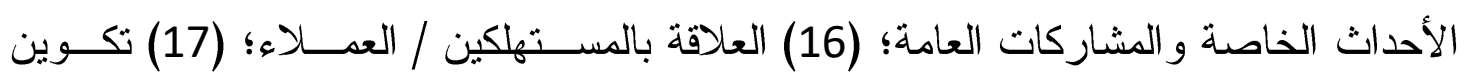
جماعات ضغط [السياسيين و الفنانين و المشاهير]؛ [العلاقة بالجامعات و الكليات]. 9- توصلت جواد (2011) إلى وجود ضعف في العلاقة بين أقسام العلاقــات العامـــة الإدارة

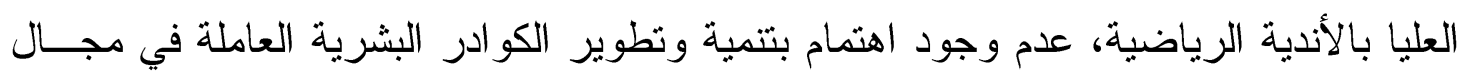

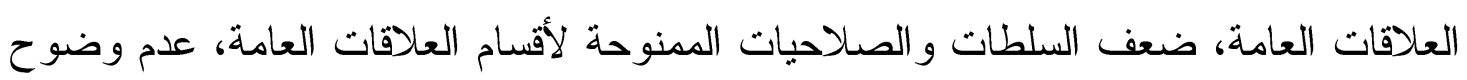

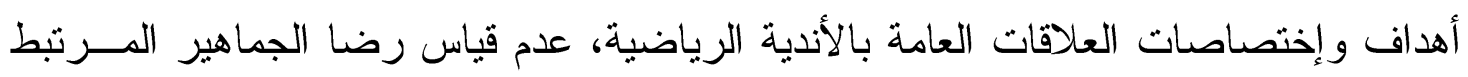

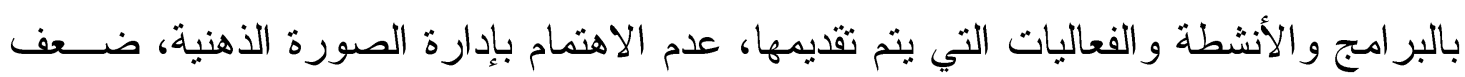

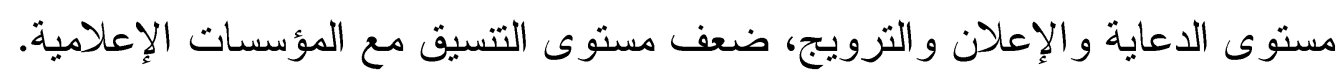

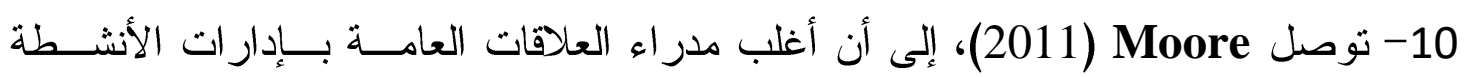

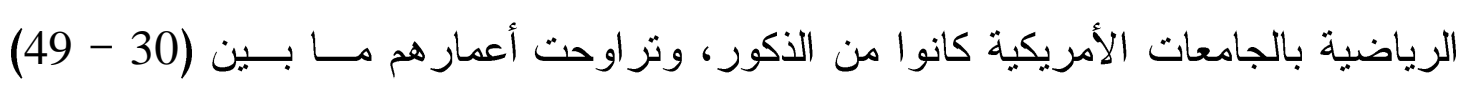

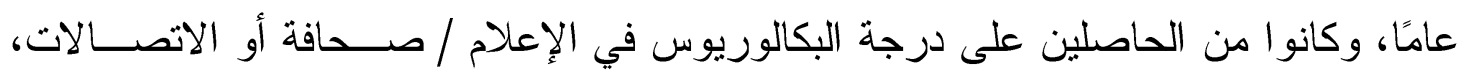

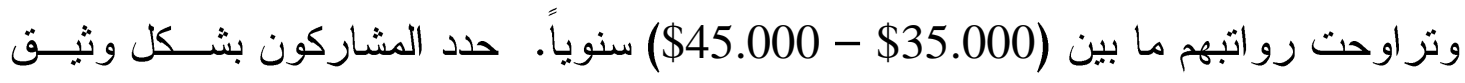

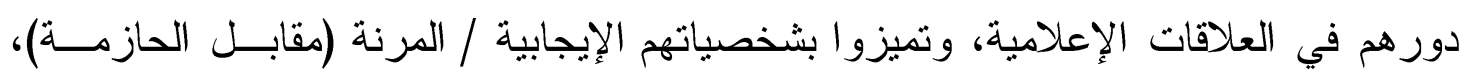

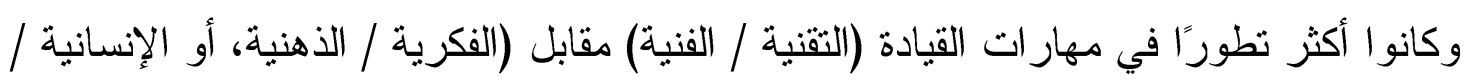

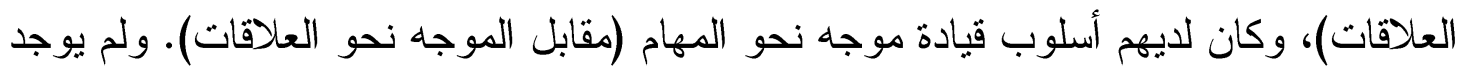

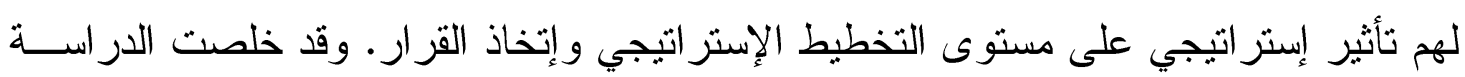

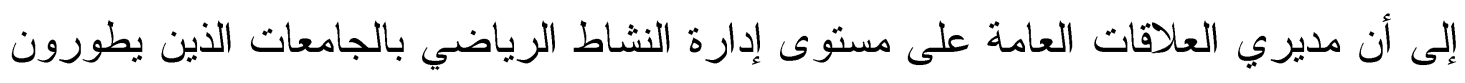

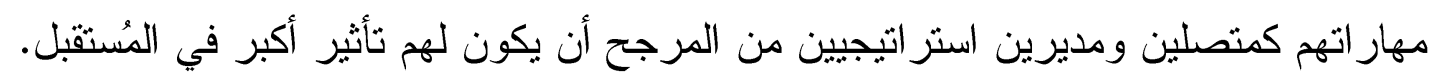

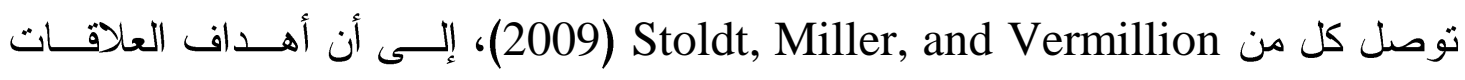


العامة في الهيئات الرياضية بناء الوعي، و السمعة والصورة الذهنية الإيجابية، وعمل الدعاية

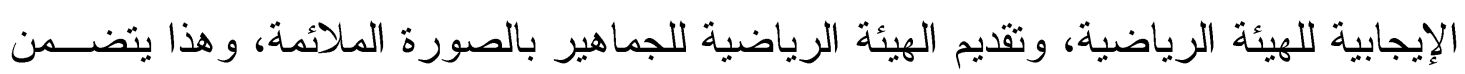

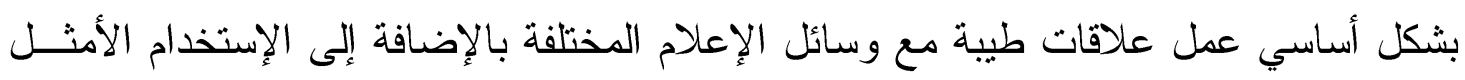

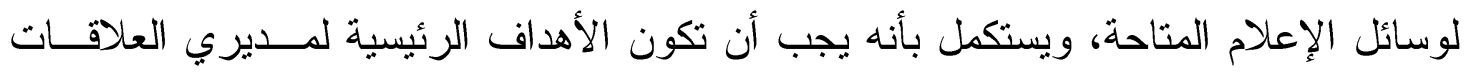

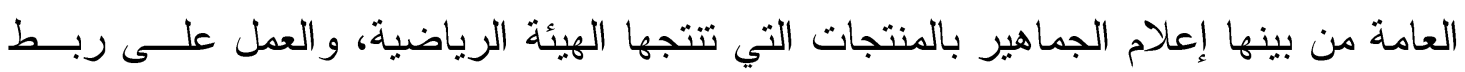

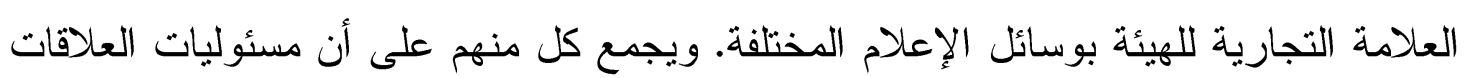

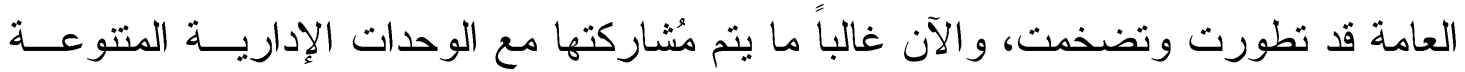

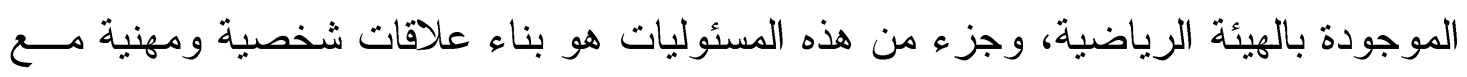

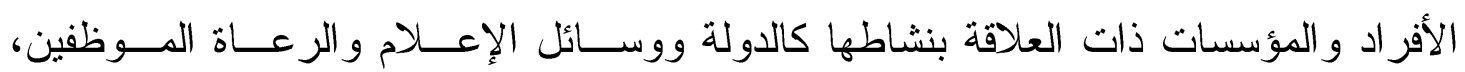

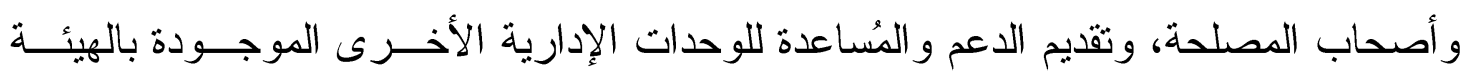
و التتسيق بينها من أجل تحقيق الأهداف العامة للهيئة الرياضية.

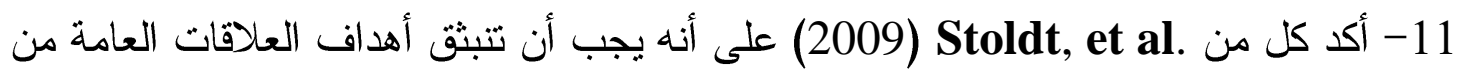

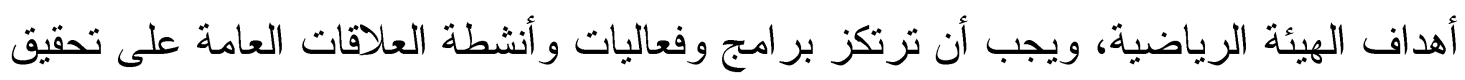

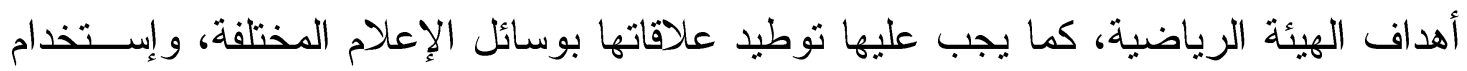

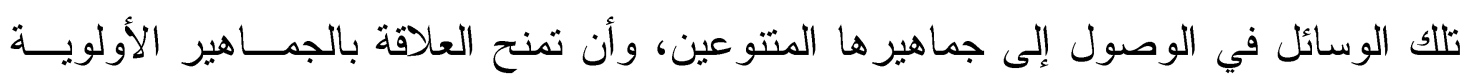

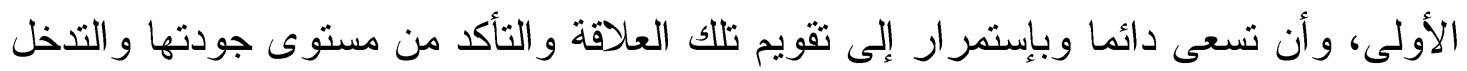

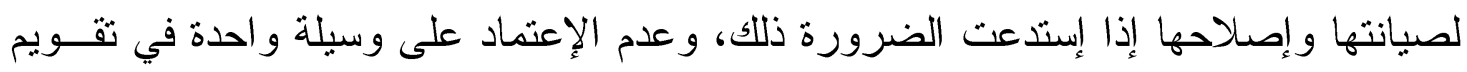
أداء العلاقات العامة، و العمل على توفير أكثر من وسيلة يمكن إستخدامها في تقويمها.

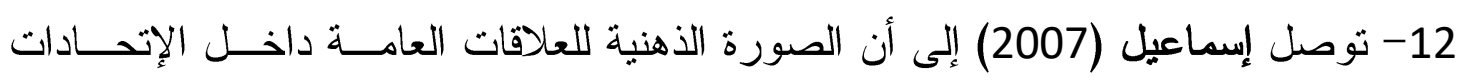

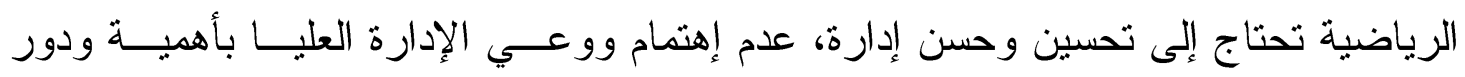

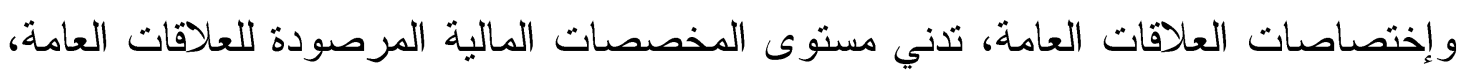

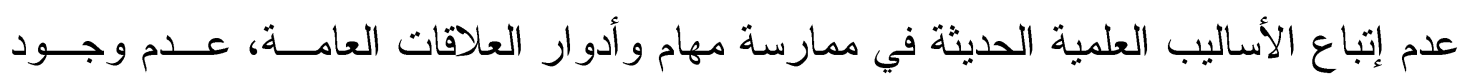

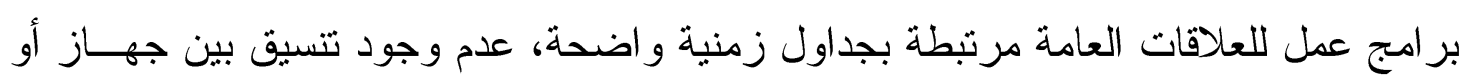

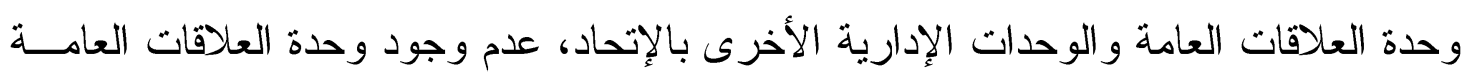

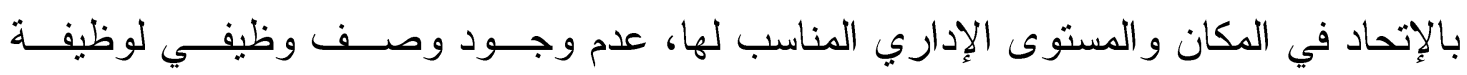

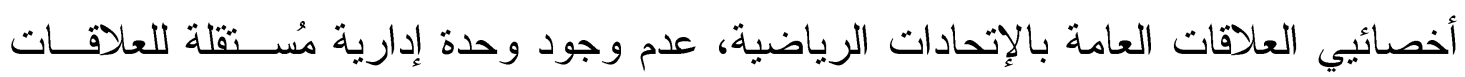

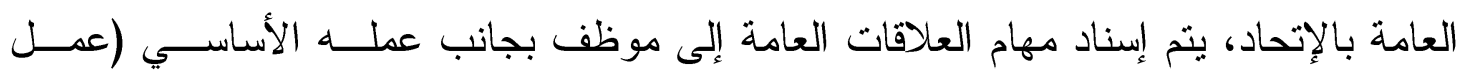

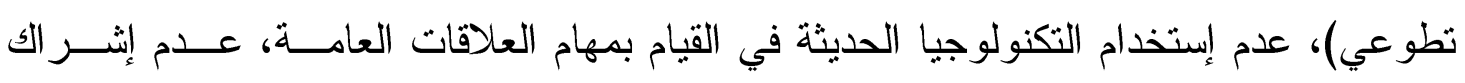

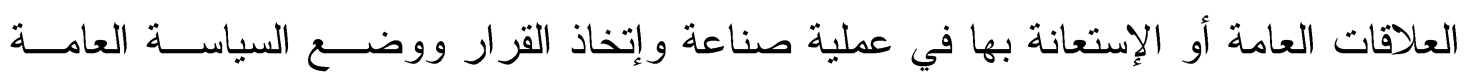


بالإتحاد، عدم تو افر كوادر بشرية مؤهلة ومدربة للإضطلاع بمهام و إختصاصات العلاقــات

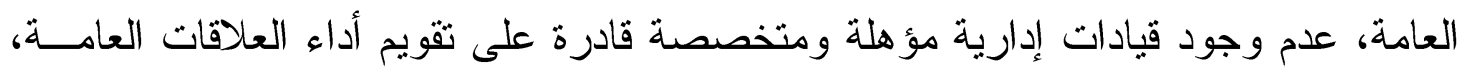

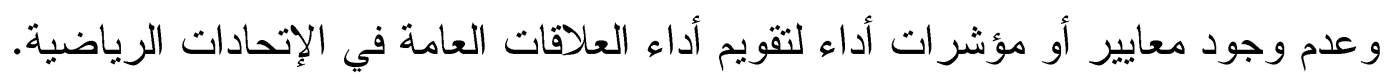

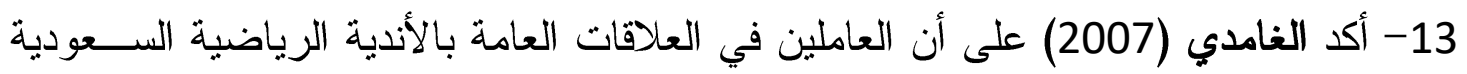

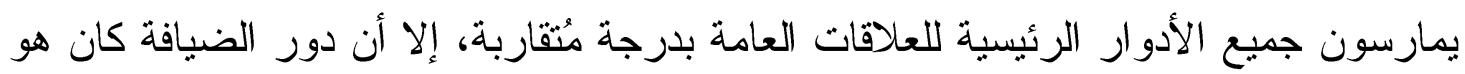

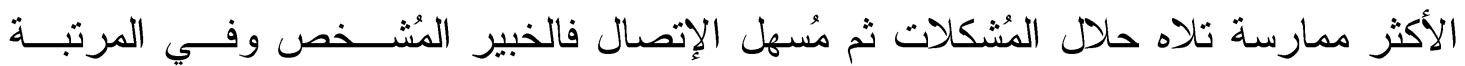

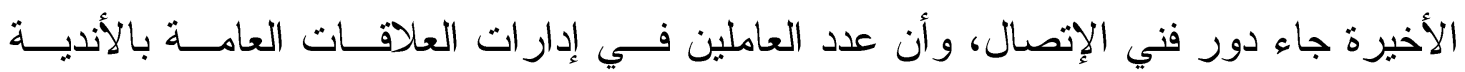

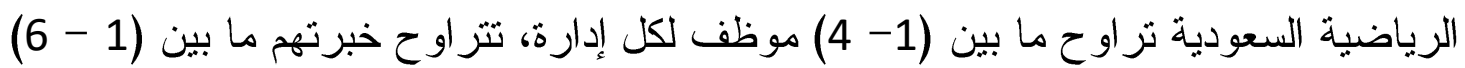

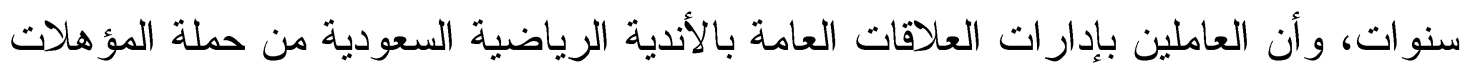

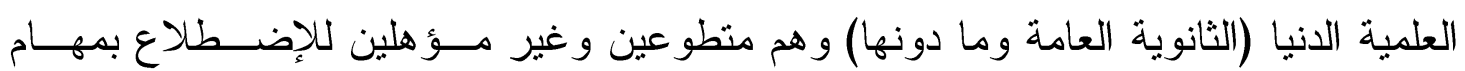

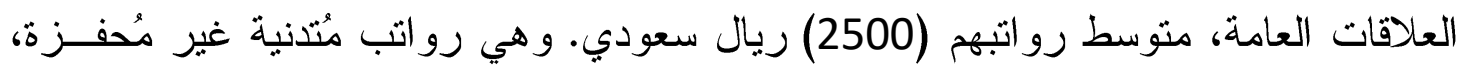

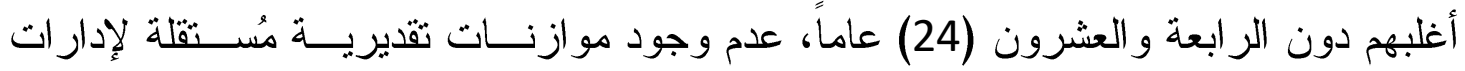

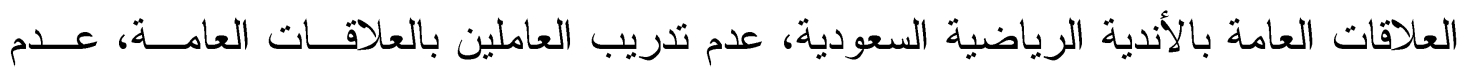

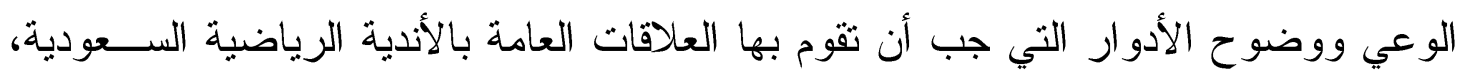

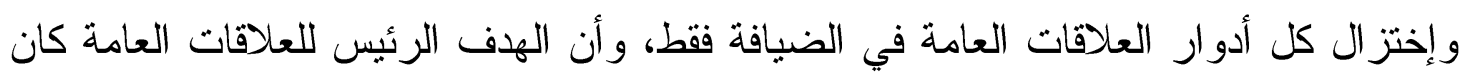

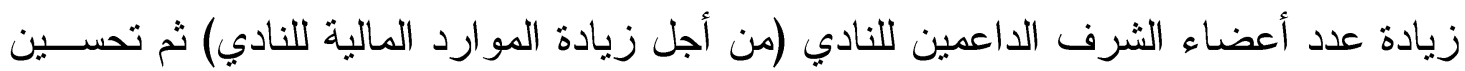
الصورة الذهنية للنادي.

14- توصل Anderson (2006) أهمية العلاقات العامة وتأثير ها القوي على إنجاح الإتحاد

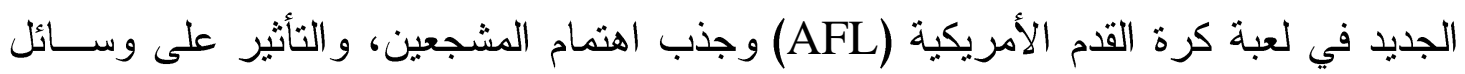

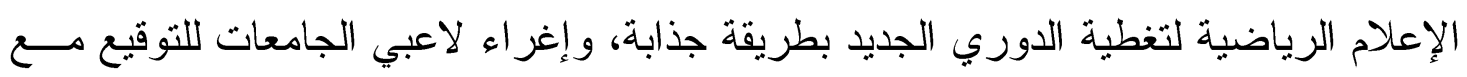

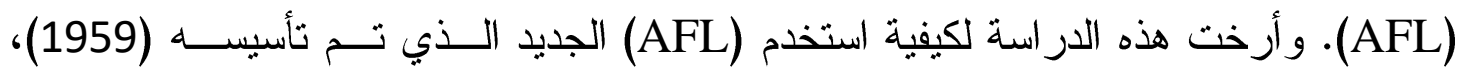

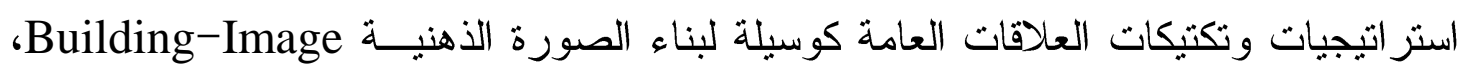

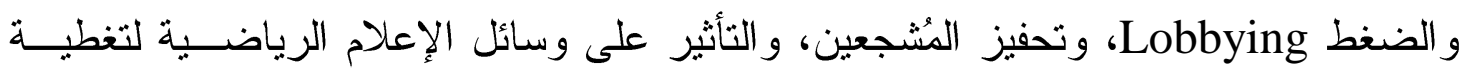

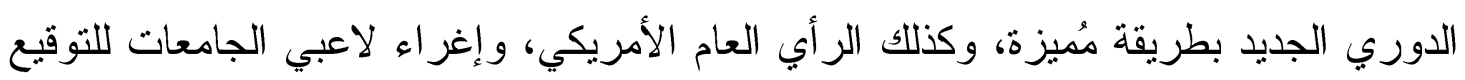

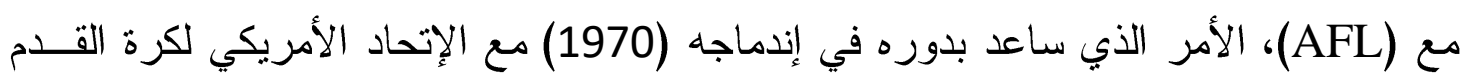
(NFL)

15- قام كل من Boyle and Haynes (2006) بتحليل إدارة الإحتر اف في كـرة القــدم

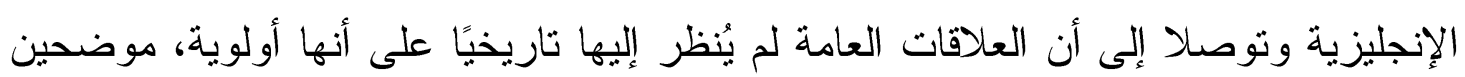

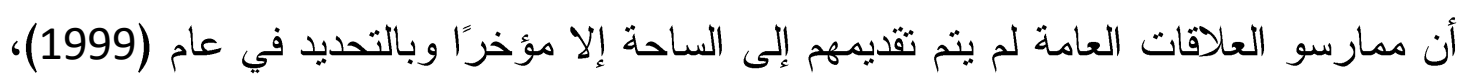




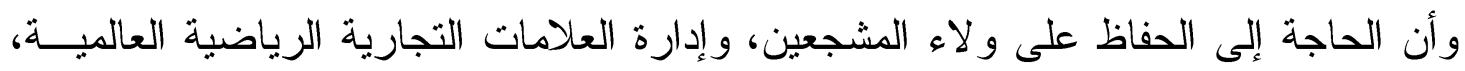

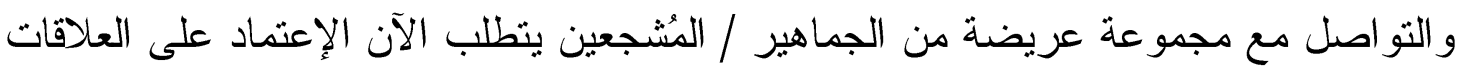
العامة أكثر من أي وقت مضى معي. 16- توصل Hopwood (2005 a) Hod إلى أن الهيئات الرياضية المعاصرة أصبحت تُرك أنها

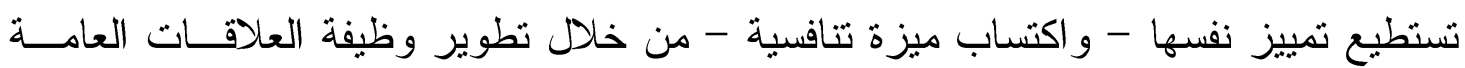

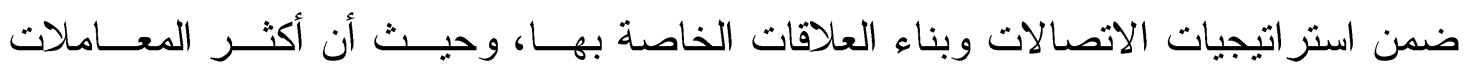

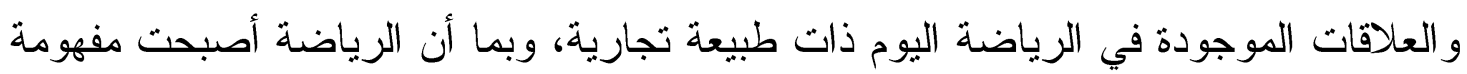

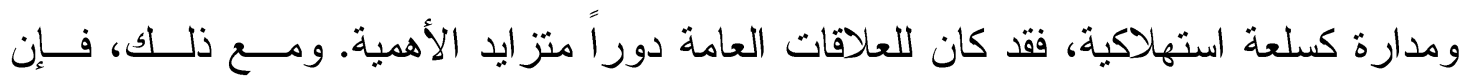
استخدام العلاقات العامة في إدارة العلاقات الرياضية في المملكة المتحدة ليس و اضحكًا دائمًا.

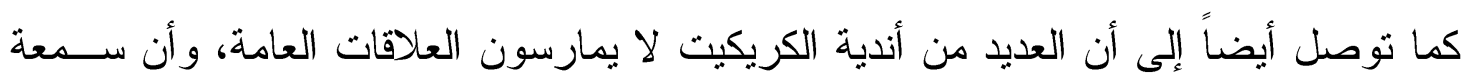

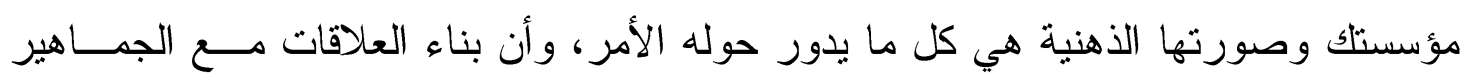

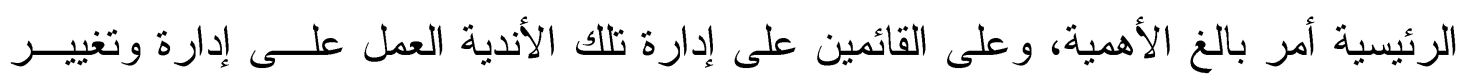

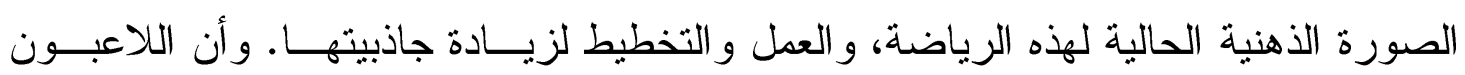

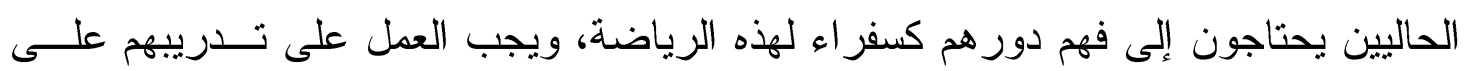

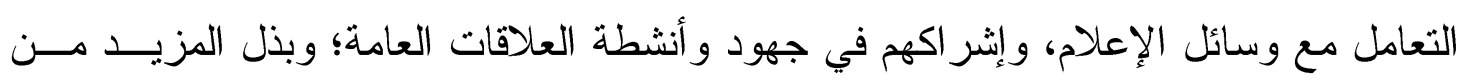

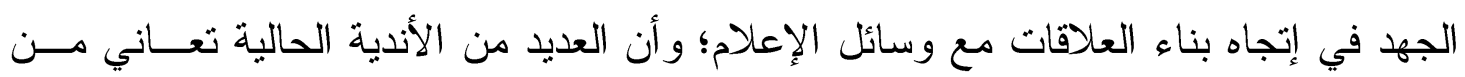

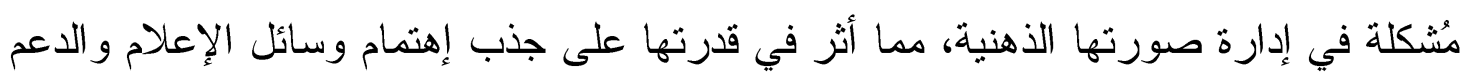

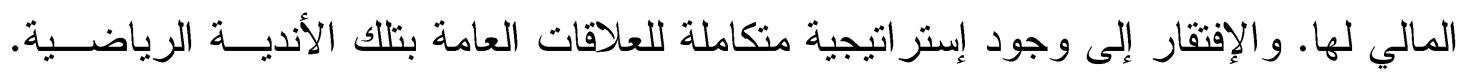

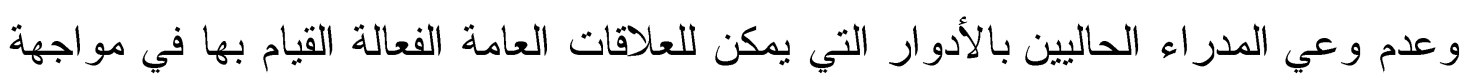
التحديات التي تتعرض لها ثلإك الأندية، و الدساهمة في تحقيق أهدافها.

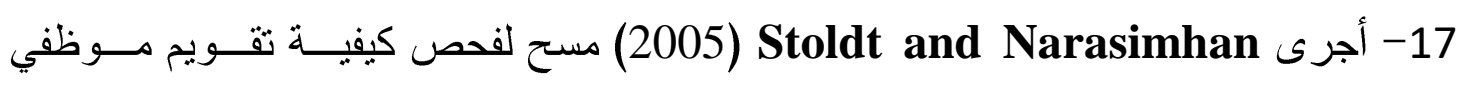

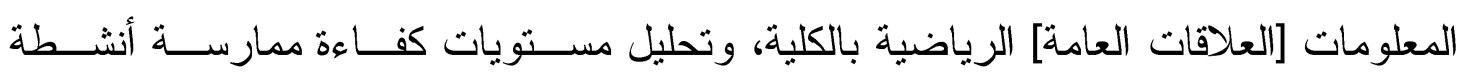

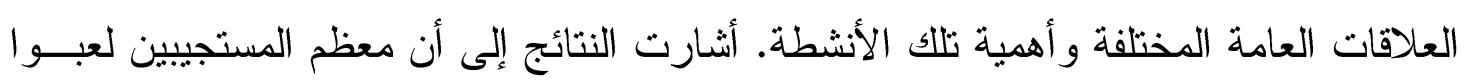

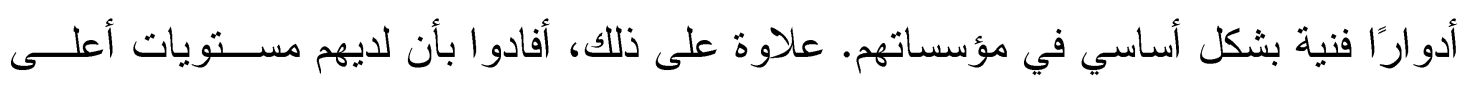

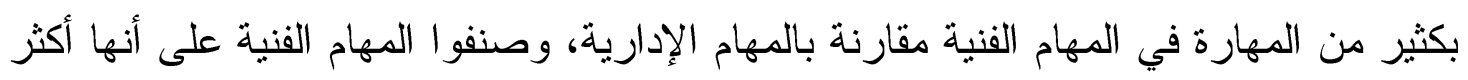

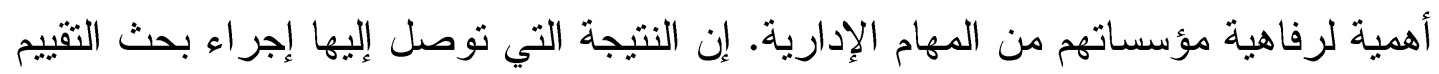

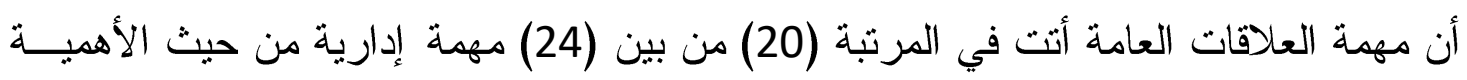
في رأي أعضاء الجهاز الوظيفي بإدارة النشاط الرياضي بالجة فالجامعة.

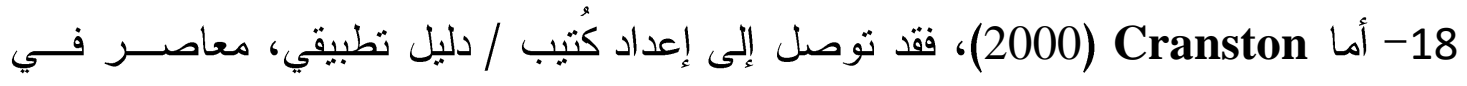


العلاقات العامة لِدُدر اء النشاط الرياضي في المدارس الثانوية. يوفر هذا الكتيب دليلًا لأنثــــة

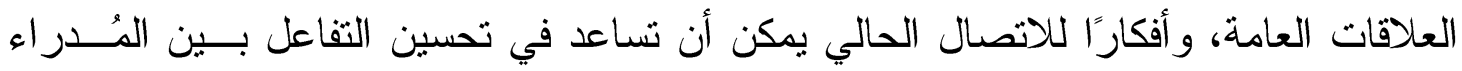

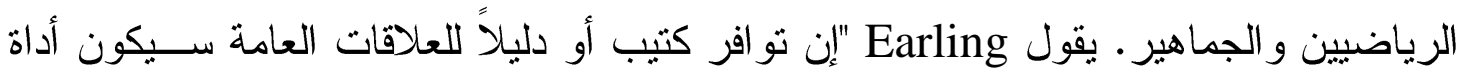

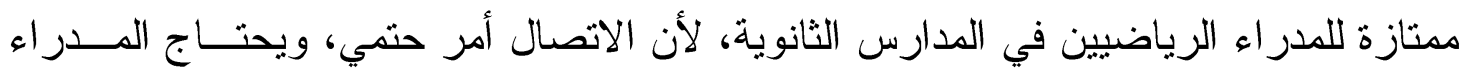

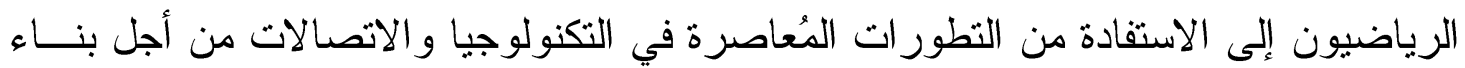

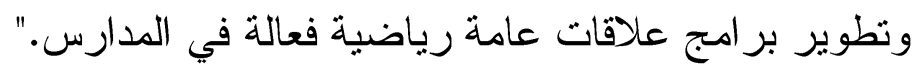

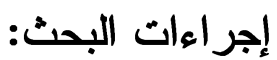

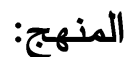
إستخدم الباحث المنهج الوصفي "در اسة مسحية"، نظر أ لمناسبتها وطبيعة هذا البحث.

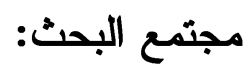
الإتحادات الرياضية الأولمبية بالمملكة العربية السعودية.

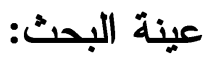
المديرون التنفيذيين بالإتحادات الرياضية الأولمبية السعودية، و عددهم (22) مدبراً تتفيذياً. جدول (1)

\section{عينة البحث}

$\mathrm{N} / 22$

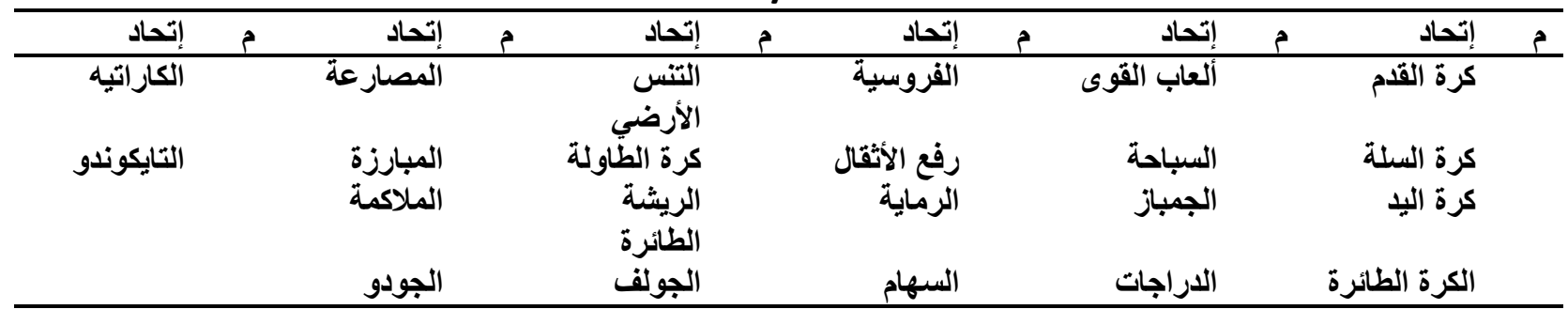

المجال الزمني : تم إجر اءء هذا البحث في العام الجامعي (2020م - 2021م).

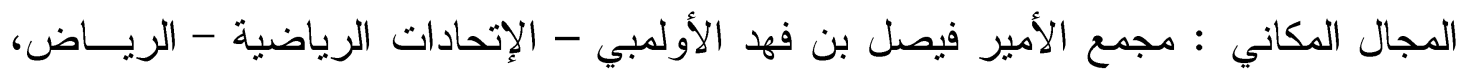
المملكة العربية السعودية.

$$
\text { أداة جمع البيانات الإستبيان. }
$$

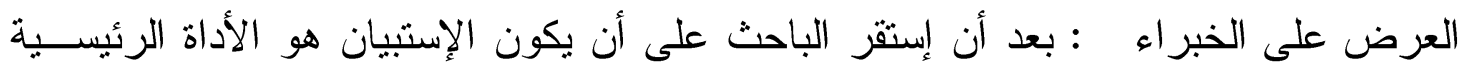

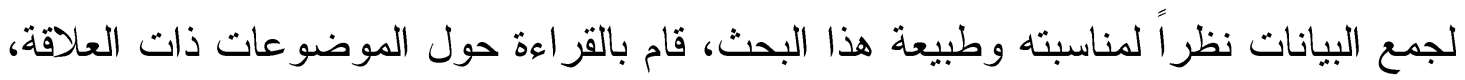

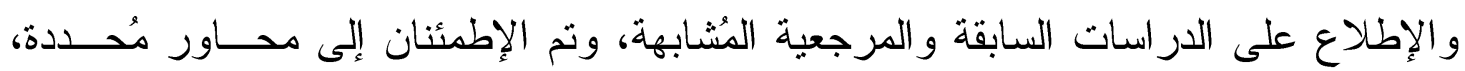

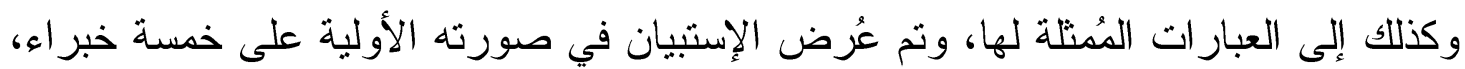

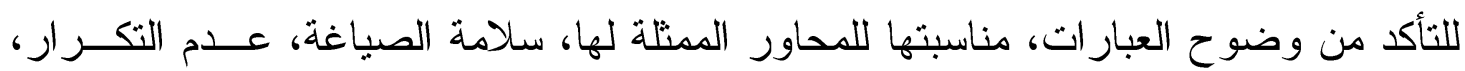


و إبداء أية ملاحظات يرونها من الأهمية بمكان بحيث يُحقق هذا الإستبيان الهدف منه. وقد إستخدم الباحث ميز ان التقدير الخماسي لليكرث، لحساب تقديرات أفراد العينة، وقد أســفر ذلك العرض عن التوصل إلى إستبيان جاءت مو اصفاتها كما هو موضح في جدول (1).

$$
\text { جدول (2) }
$$

مو اصفات أداة جمع البيانات - الإستبيان - بعد العرض على الخبراء

$\mathrm{N} / 5$

\begin{tabular}{|c|c|c|c|c|c|}
\hline الخامس & الرابع & الثالث & الثانِي & الأول & المحور \\
\hline تحليل الأداء & تحليل الأداء & تحليل الأداء & تحليل الأداء & تحليل الأداء & إسم المحور \\
\hline الإداري في تقويم & الإداري في تنظيم & الأداري لشئون & الإداري للسمعة، & الإداري لثبكات & \\
\hline أداء (أُدوار) & شئونون العلاّقات & الضيافَة & والُصورة الذهنية & العلاقاتَ & \\
\hline العلاقات العامة & العامة بالإتحادات & بالإتحادات & بالإتحادات & بالإتحادات & \\
\hline بالإتحادات & الرياضية & ألرياضية & الرياضية & ألرياضية & \\
\hline ألرياضية & الأولمبية & السعودية. & الأولمبية & الأولمبية & \\
\hline السعودية. & السعودية. & & السعودية. & السعودية & \\
\hline 5 & 14 & 8 & 19 & 10 & 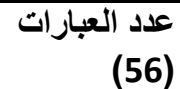 \\
\hline$(56: 52)$ & $(51: 38)$ & $(37: 30)$ & (29:11) & $(10: 1)$ & عبارات المحور \\
\hline
\end{tabular}

المعاملات العلمية لأداة جمع البيانات:

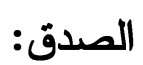

جدول (3) (3) - (3)

معامل الإتساق الداخلي للإستبيان

$\mathrm{N} / 22$

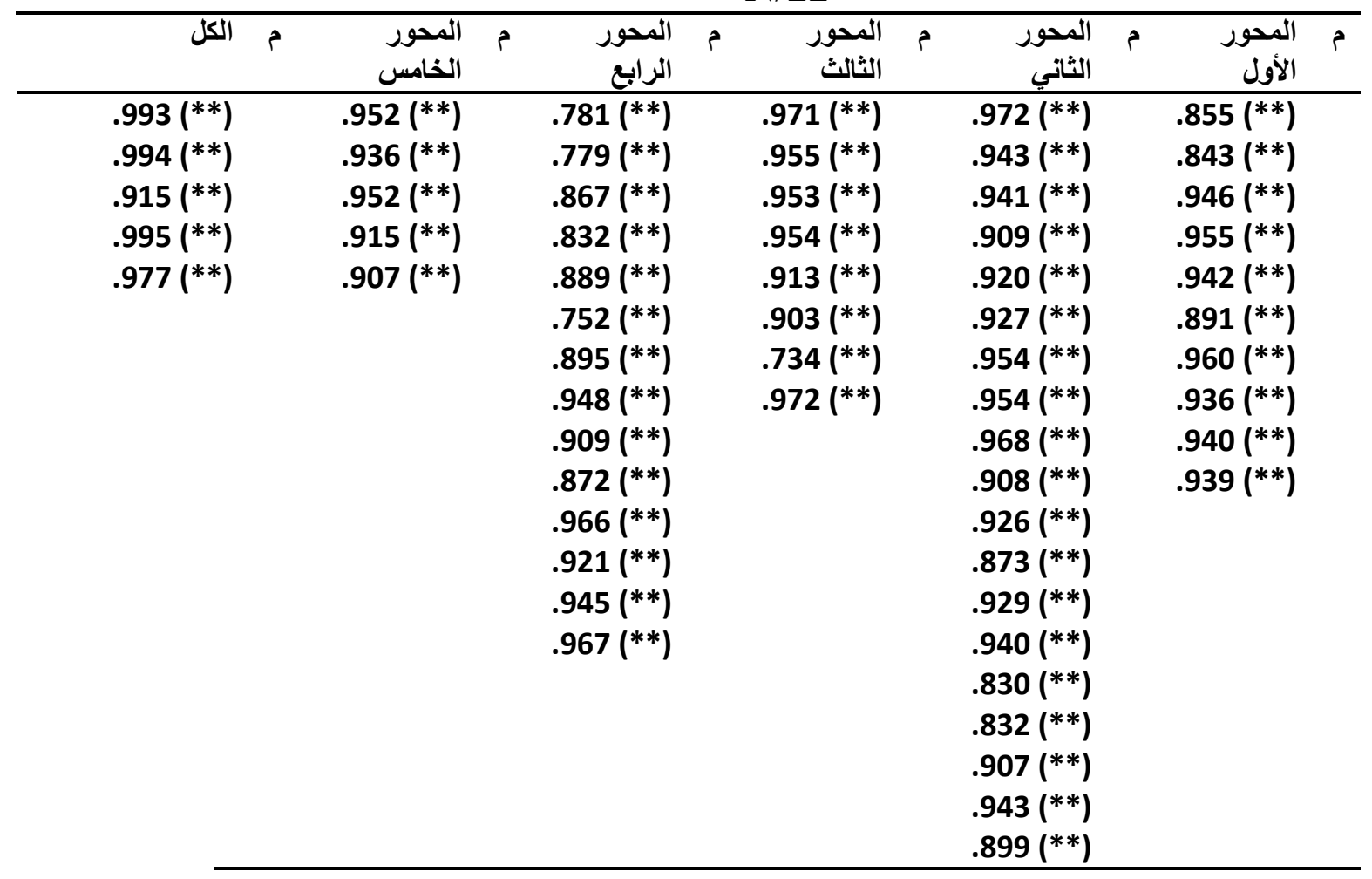

المجلة العلمية لكلية التربية الرياضية للبنين بالهرم جامعة حلوان 


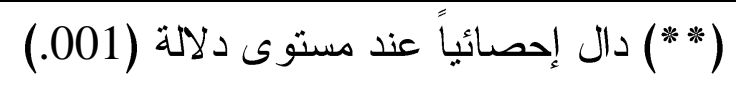

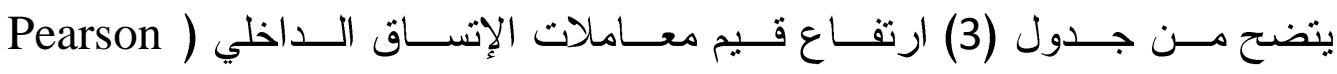

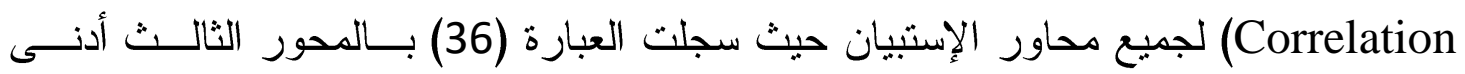
معامل إتساق داخلي على مستوى الإستبيان ككل حيث بلغت قيمته (134.)، كما سجلت العبارة

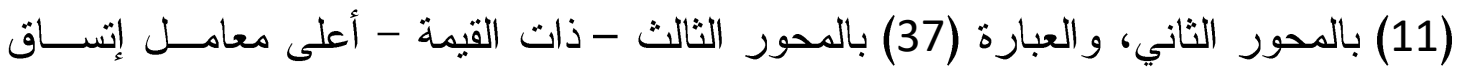

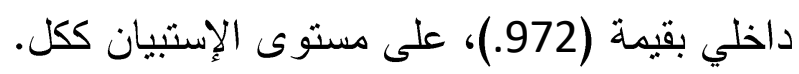

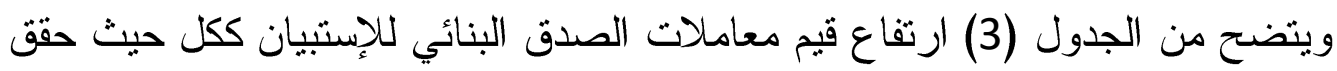

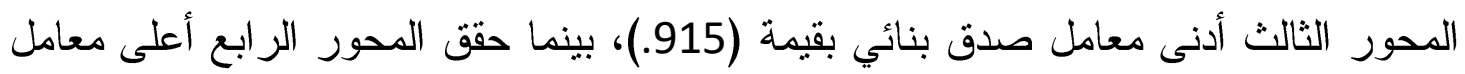

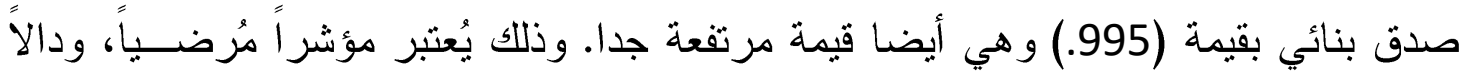

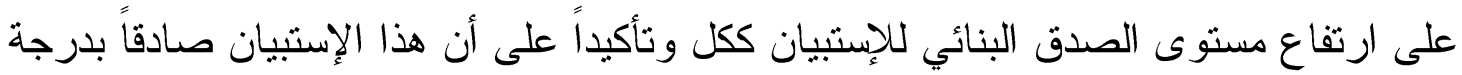
مرتفعة، وبالتالي يمكن الوثوق في نتائجه و الإطمئنان إليها.

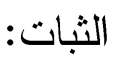

$$
\text { جدول (4) }
$$

\begin{tabular}{|c|c|c|c|c|c|}
\hline \multicolumn{3}{|c|}{ N/22 } & & & \\
\hline & & & & ستبيان & محاور \\
\hline الكل & الخامس & الرابع & الثالث & الثاني & الأول \\
\hline .985 & .961 & .971 & .962 & .988 & .977 \\
\hline
\end{tabular}

Cronbach's Alpha Coefficient معاملات ثبات

يتضح من جدول (4) أن معاملات ثبات الإستيبان مرتفعة جداً (> 7.)، و أن المحسور

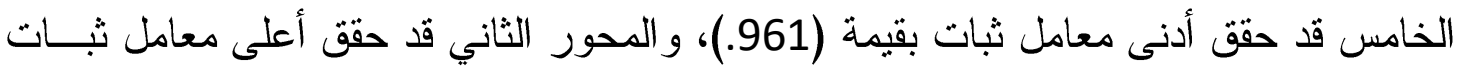

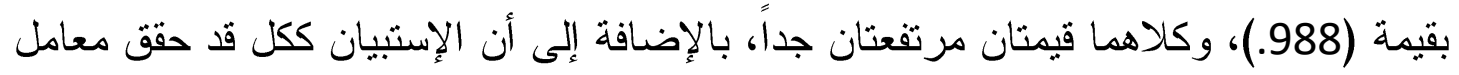

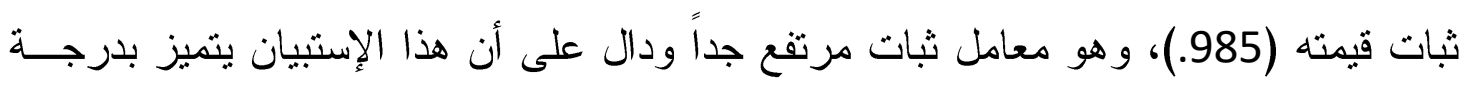
ثبات عالية، يمكن الوثوق في نتائجه و الإطمئنان إليها.

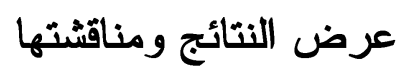
التساؤل الأول: ما و اقع الأداء الإداري لشبكات العلاقات العامة بالإتحادات الرياضية السعودية؟

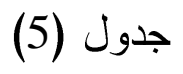

\begin{tabular}{|c|c|c|c|c|c|c|c|c|c|c|}
\hline & الأهمية & & & الدحم ع & & III & III & III & نعم & إدارة شبكات العلاقات العامة. \\
\hline الترتيب & النسبية & المعياري & الحسابي & التقفيريو & 1 & & & 4 & 5 & بالإتحادات الرياضية الأولمبية \\
\hline
\end{tabular}

تحليل الأداء الإداري لشبكات العلاقات العامة بالإتحادات الرياضية الأولمبية السعودية؟ 


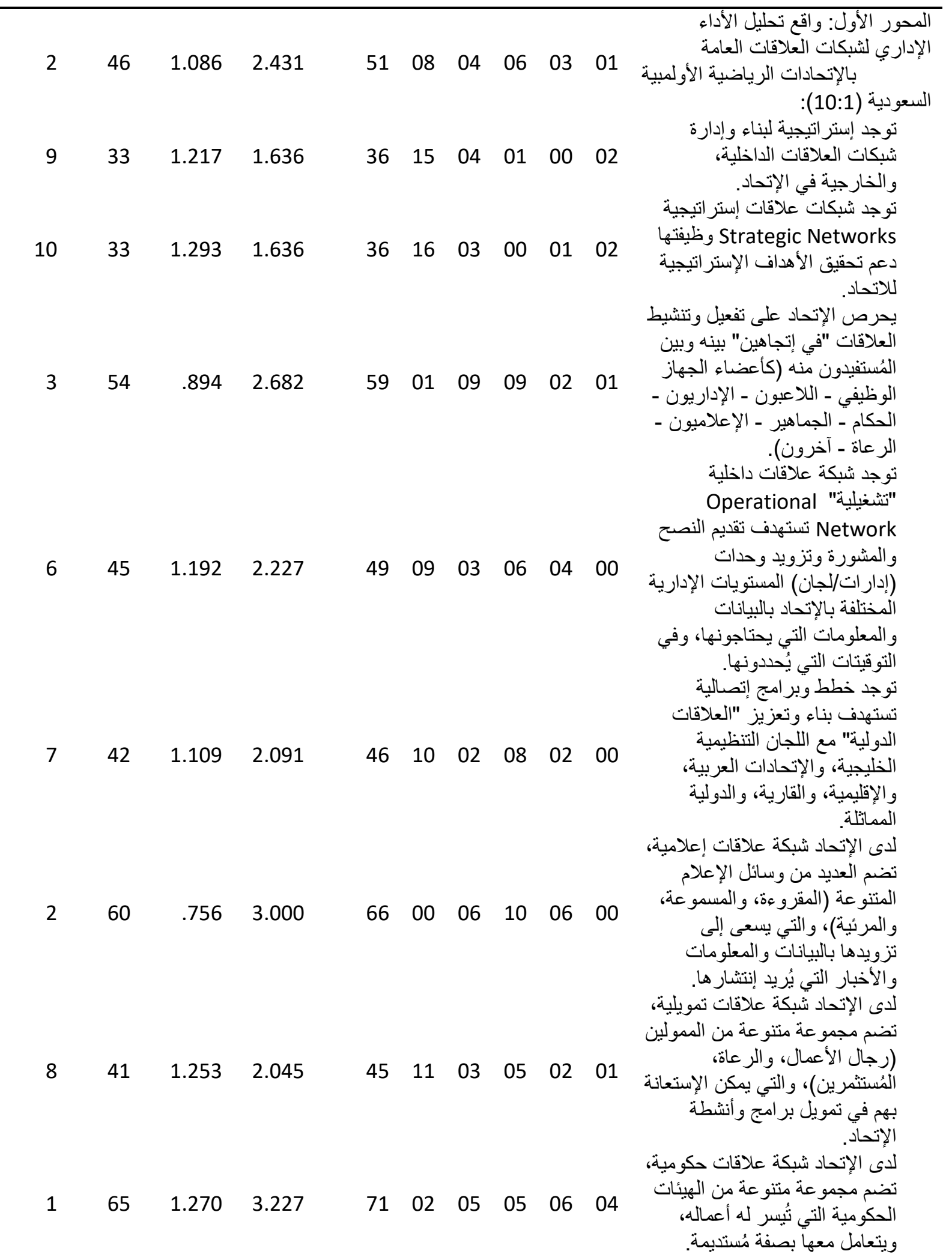


لدى الإتحاد شبكة علاقات من

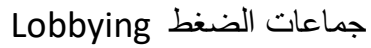
Groups

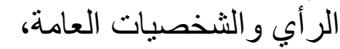
و غير هم من الثخصيات الأخرى المؤثرة في المجنمع، يتم الإستعانة

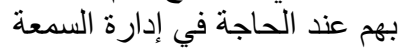
و والصورة الذهنية للاتحاد في الداخل الدادل

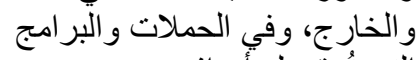
الني تُحقق له أهدافه.

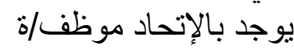

$\begin{array}{llllllllll}5 & 47 & 1.093 & 2.364 & 52 & 07 & 03 & 09 & 03 & 00\end{array}$

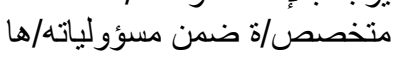
الرئيسية بناء و إدارة وتطوير مئولير شبكات العلاقات الداخلية و الخارجية في الإتحاد.

يتضح من جدول (5) أن العبارة (8) قد حصلت على أعلى أهمية نسبية (65\%) من المُديرون

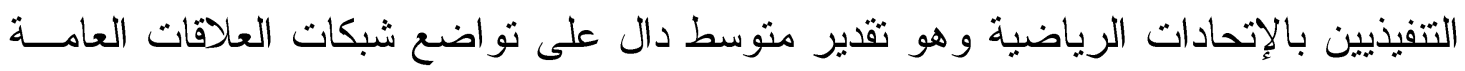

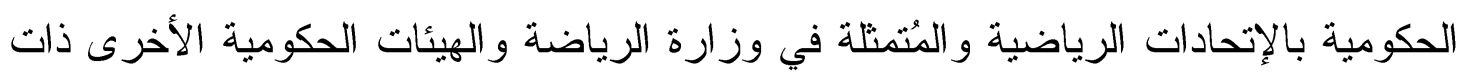

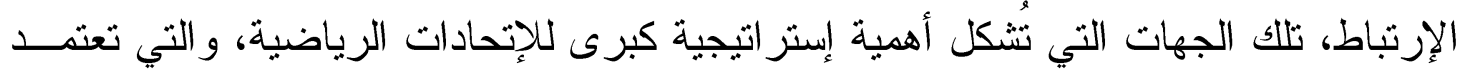

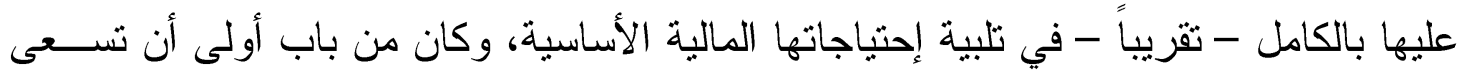

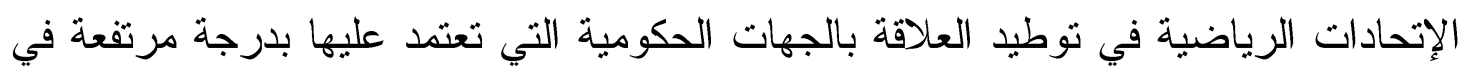

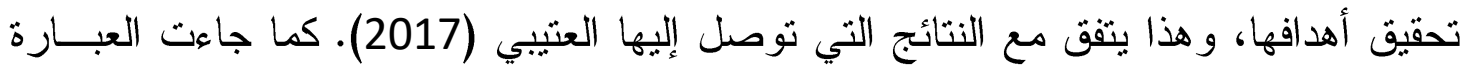

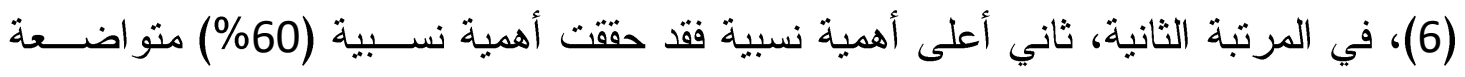

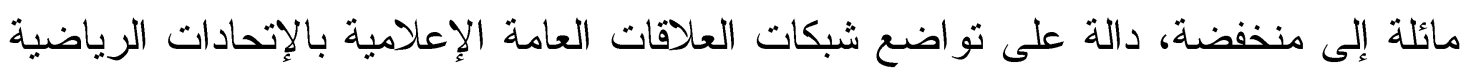

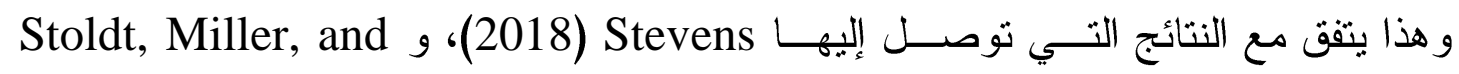

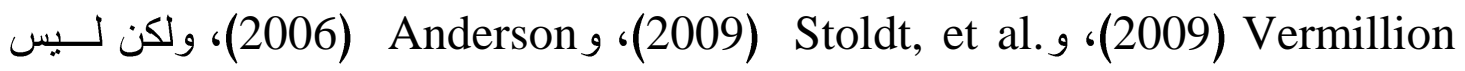

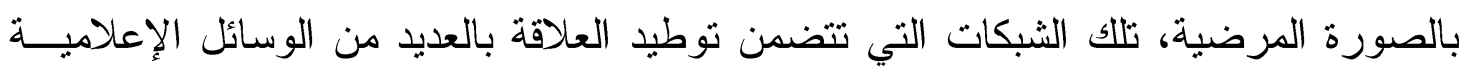

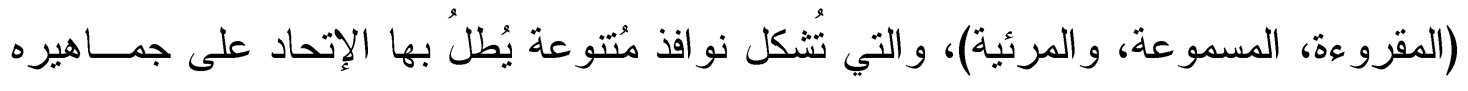

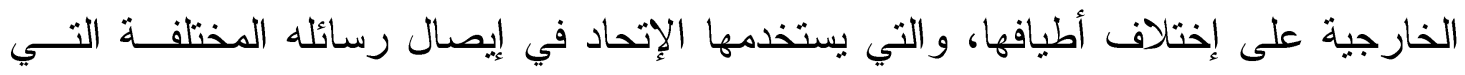

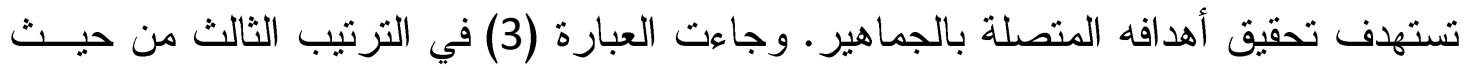

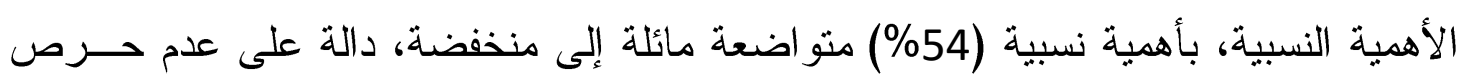

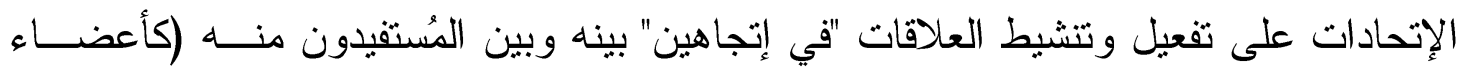

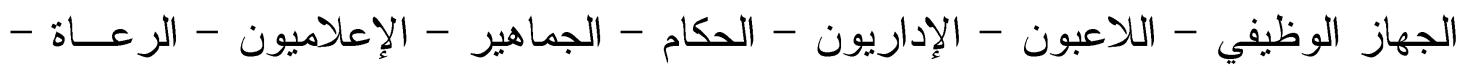

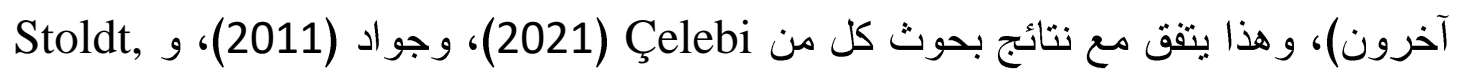
Miller, and Vermillion وجاءت العبارة (2)، في الترتيب الأخير من عبارات هذا الدحور، بأهمية نسبية (33\%) وهو واعو (2073) 
Strategic تقدير منخفض جدأ، ودال على عدم وجود شبكات علاقات عامــة إبــتر اتيجية

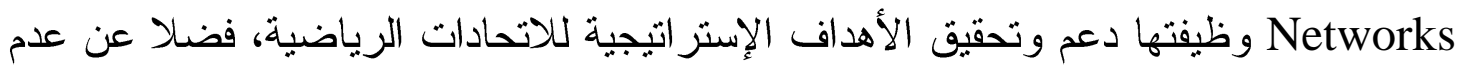

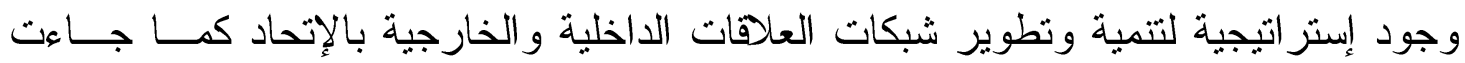

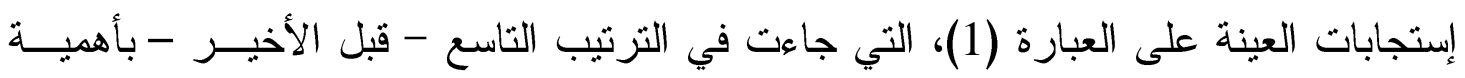

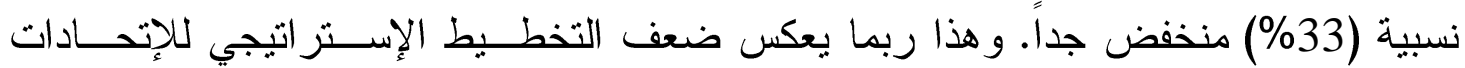

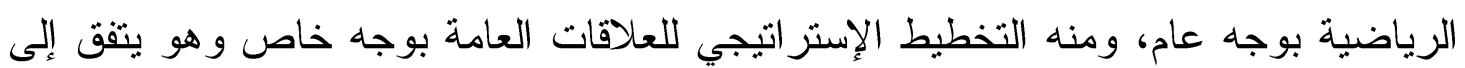
حد كبير مع ما وصلت إليه نتائج بحوث كل من الحجرف (2020)، و و

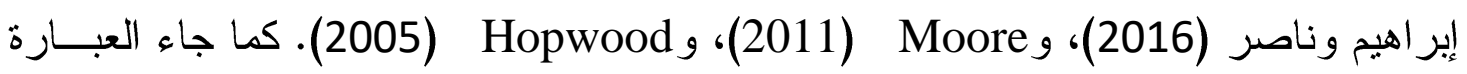

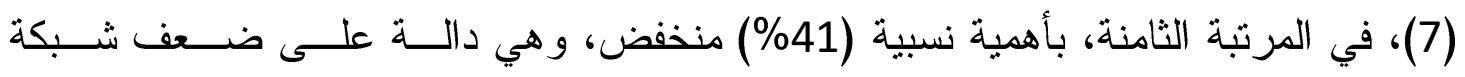

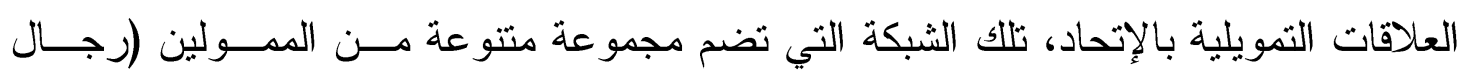

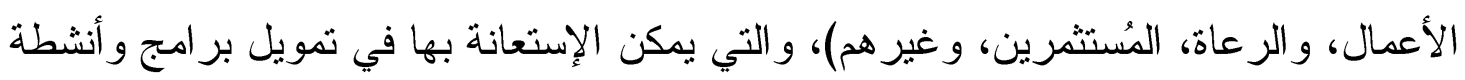

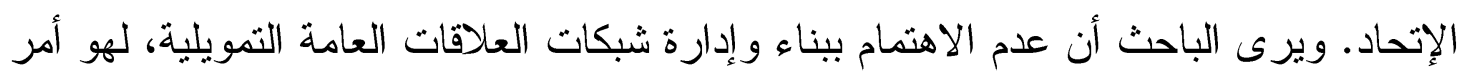
طبيعي جداً، حيث يرجع الأمر في ذلك إلى أن الإتحادات الرياضية السعودية تعتمد في تمويلها لإنها

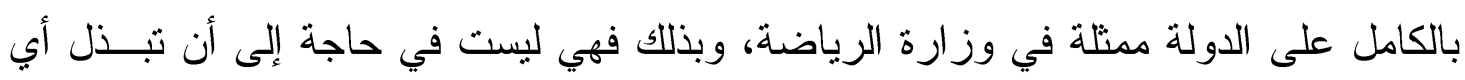
جهد في بناء شبكات علاقات عامة بهدف تتويع مصادر ها التمويلية.

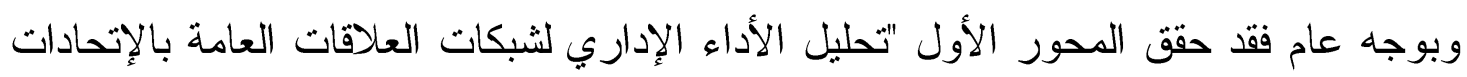

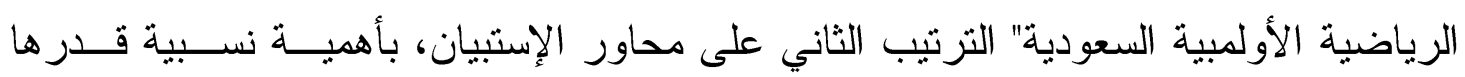
(46\%)، منخفض، حيث عكست إنخفاضاً واضحاً في مستوى إدارة شبكات العلاقات العامــة الإنة الداخلية والخارجية بالإتحادات الرياضية الأولمبية السعودية.

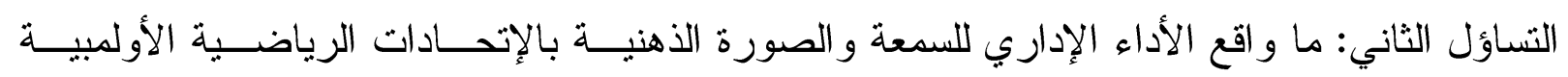
السعودية؟

جدول (6)

تحليل الأداء الإداري للسمعة والصورة الذهنية بالاتحادات الرياضية الأولمبية السعودية. المجموع المتوسط الإنحراف الأهمية الترتيب

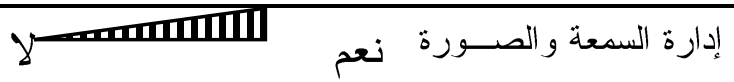
م الرياضــية الأولمبيـــة 


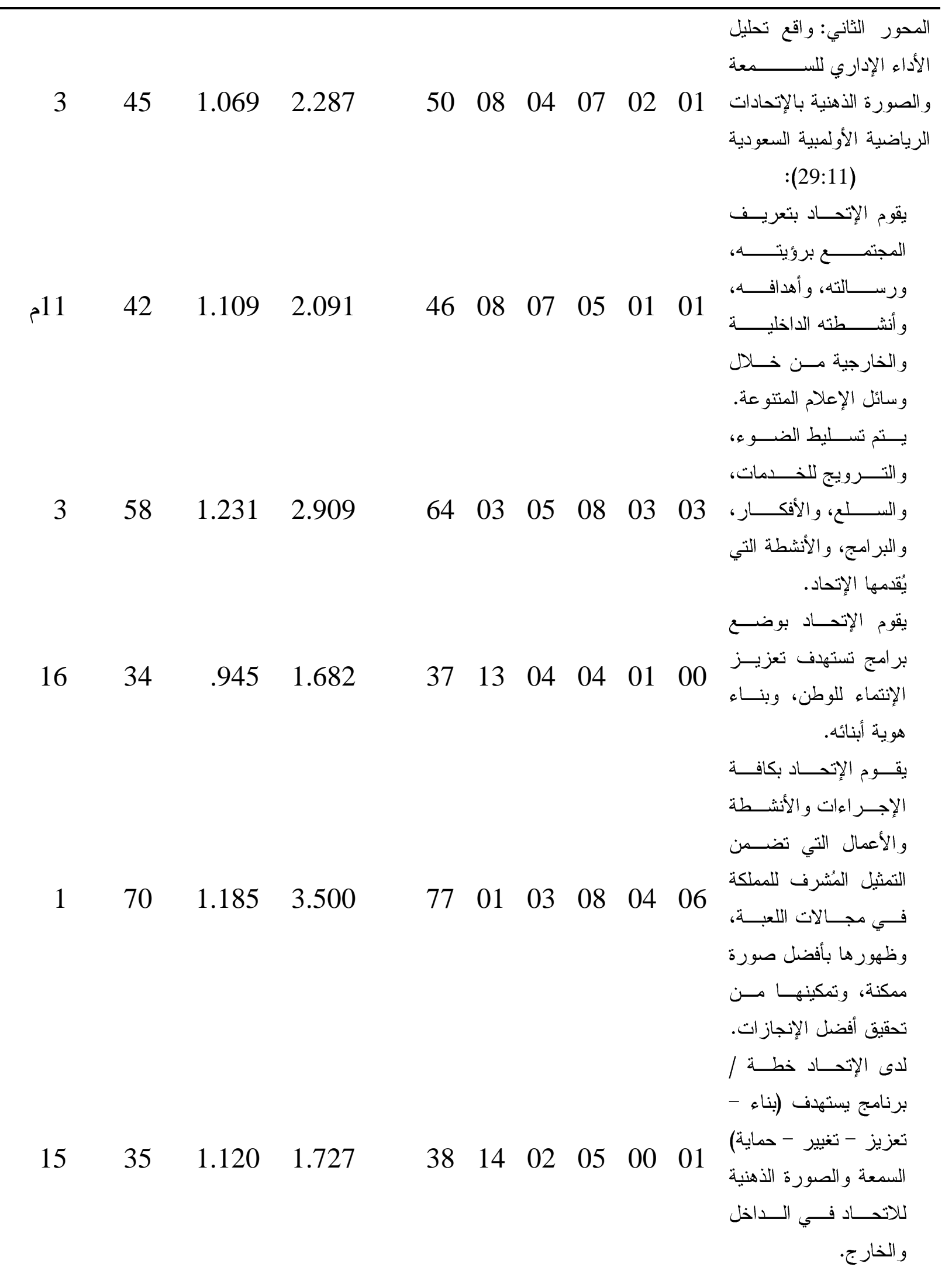




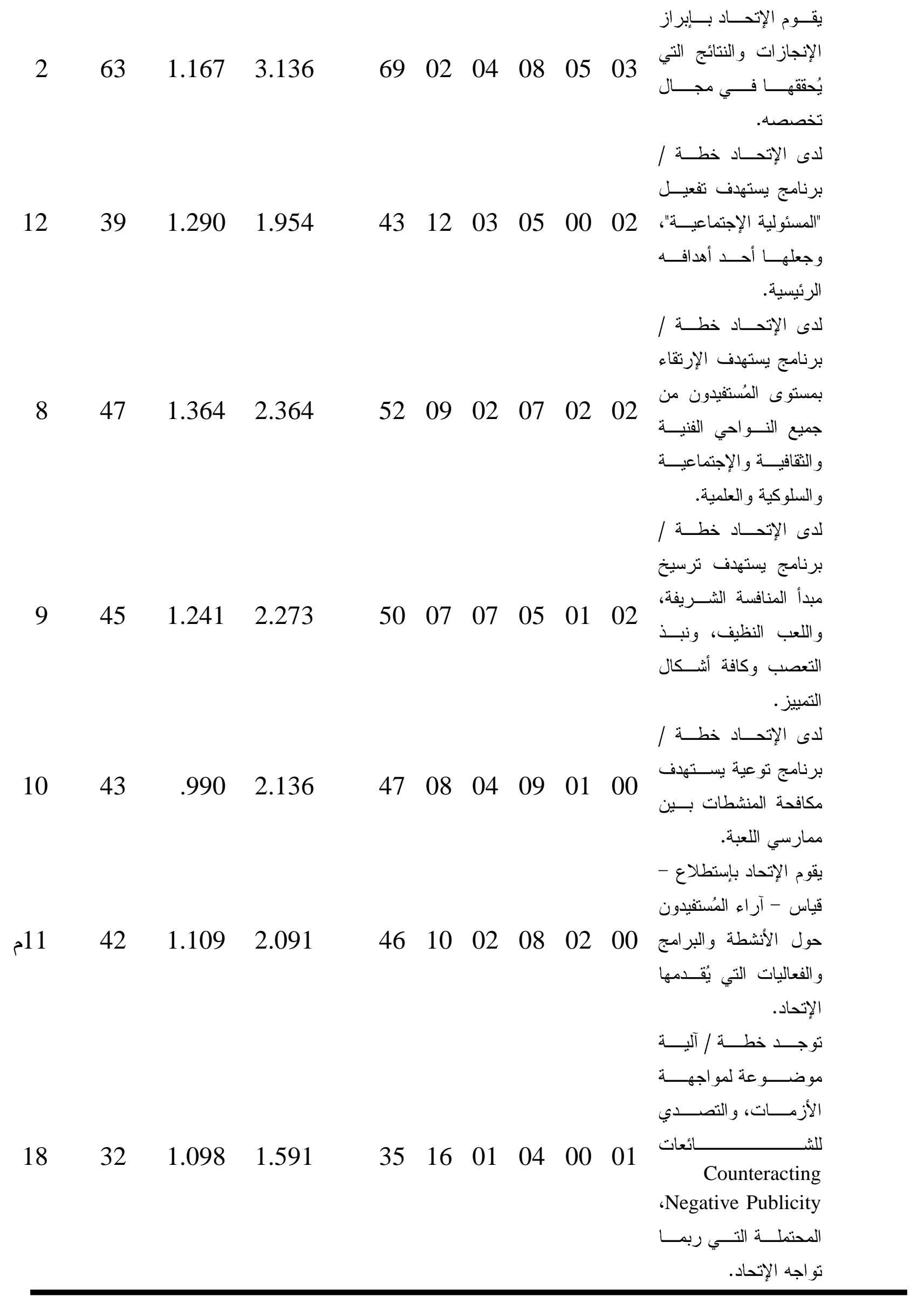




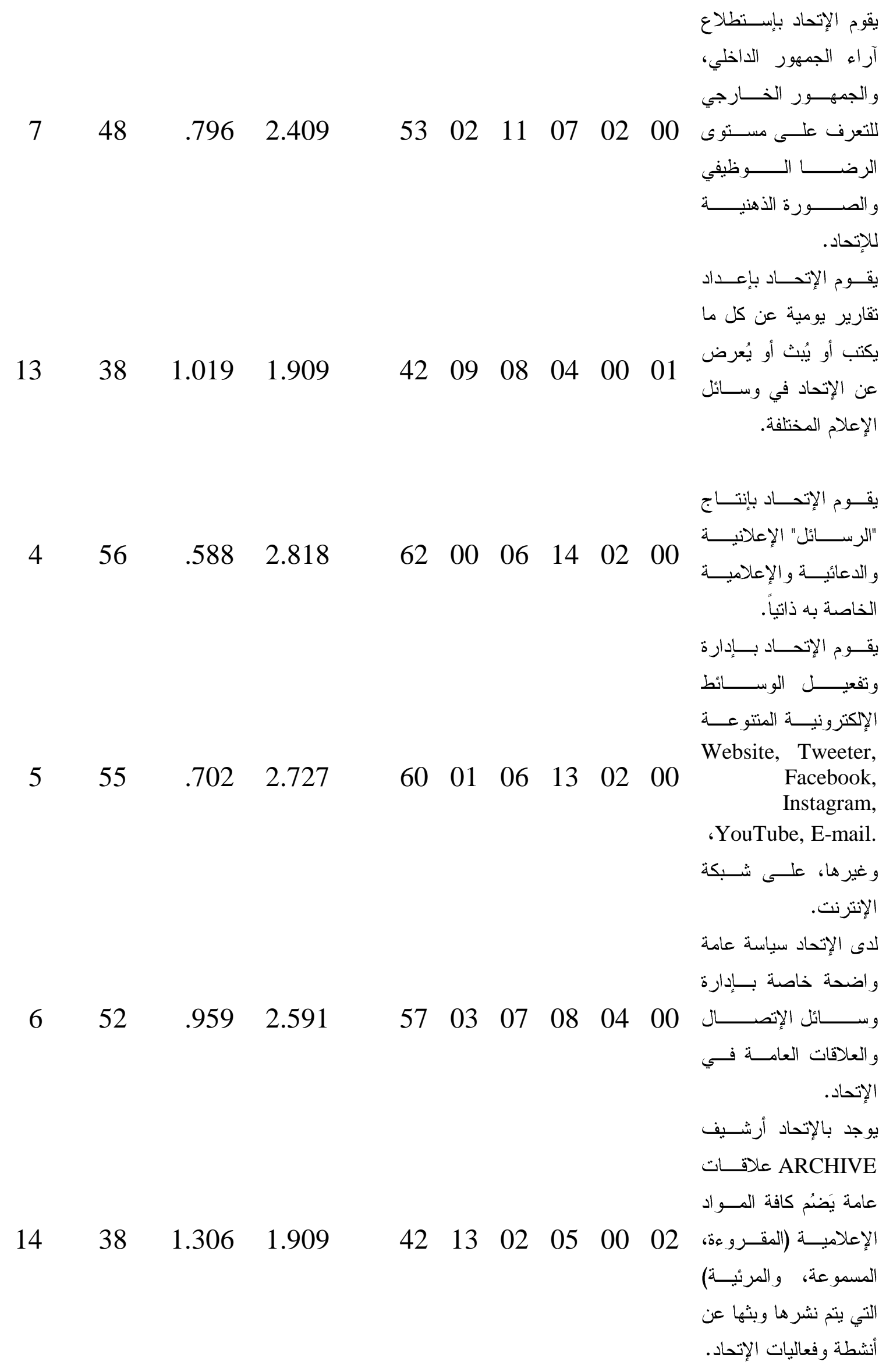


$\begin{array}{llllllllll}17 & 33 & 1.093 & 1.636 & 36 & 15 & 02 & 04 & 00 & 01\end{array}$

$$
\text { يوجد بالإتحساد وحسدة }
$$

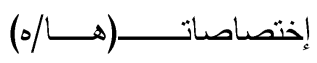

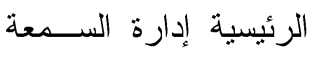

و الصورة الذهنية للاتحاد

في الداخل والخارج.

ويتضح من جدول (6) أن العبارة (14) قد حققت أعلى أهمية نسبية (70\%) وهي قيمة تعتبر

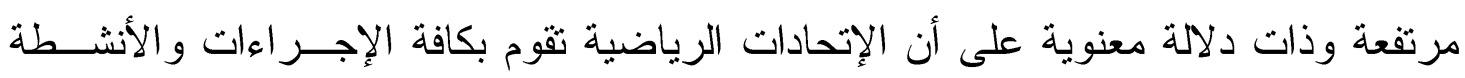

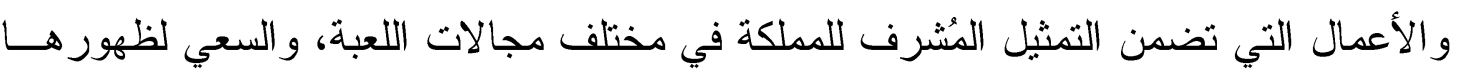

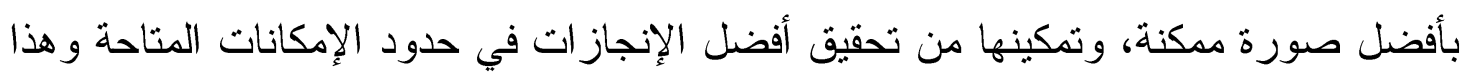

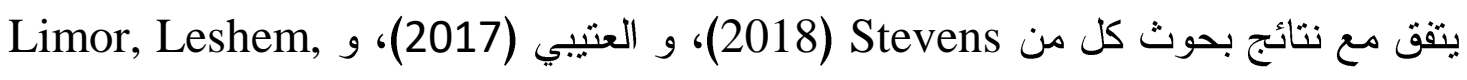
Stoldt, Miller, and Vermillion و Mendelzis

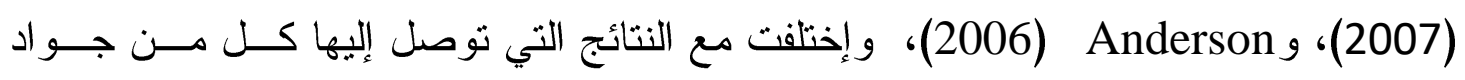

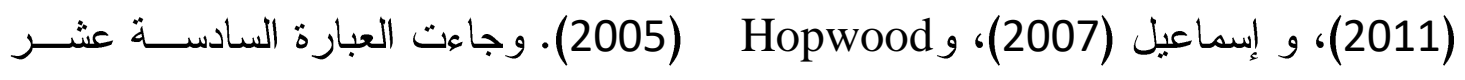

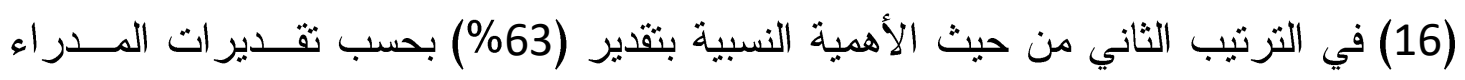

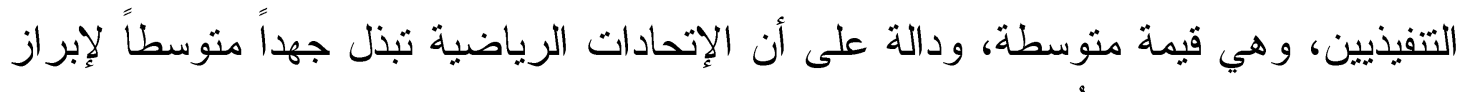

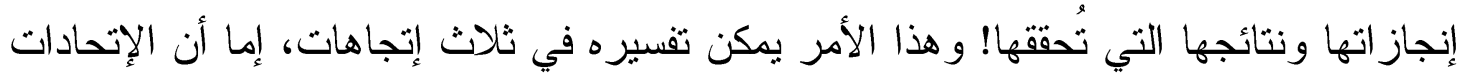

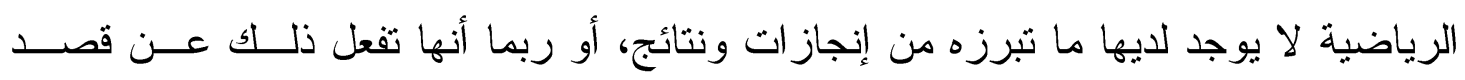

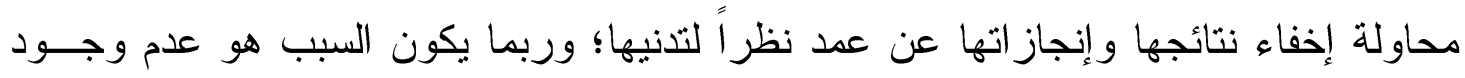

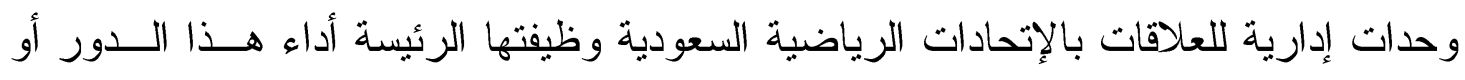

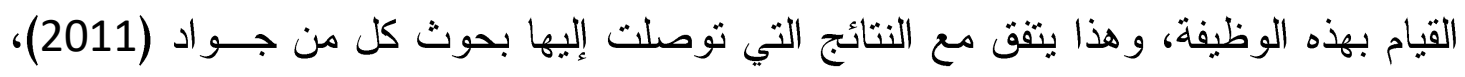

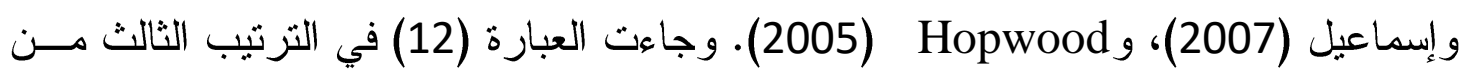
حيث أهميتها النسبية بقيمة قدرها (58\%) وهي قيمة متوسطة، ودلالة علــى أن الإتحــادات

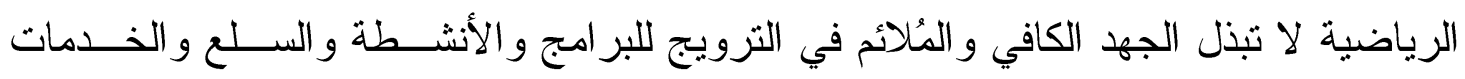

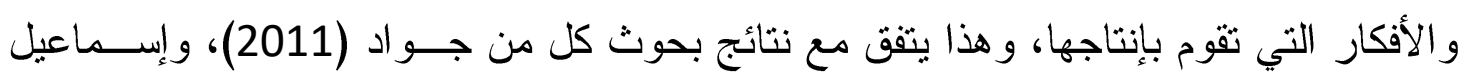

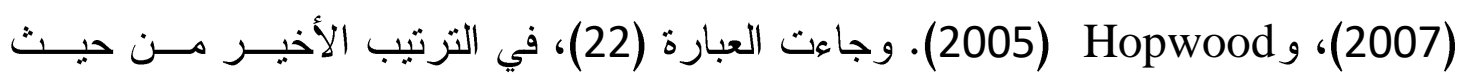

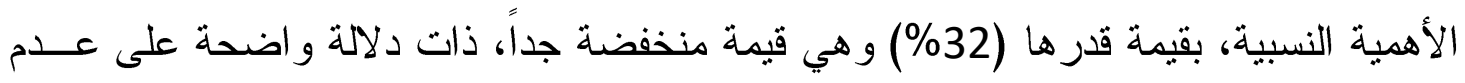

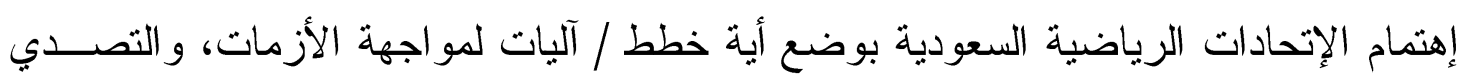

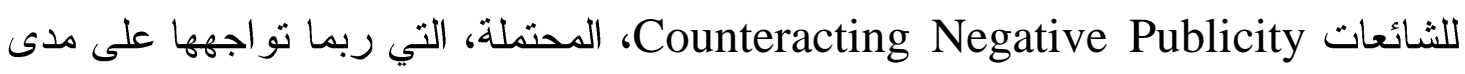
القصير، المتوسط و الطويل علماً بأن ذلك يُعتبر أحد الإختصاصات الرئيسة للعلاقات العامــة فئة 
بحسـب Limor, Leshem, \& Mendelzis (2013)، و Anderson) (2006)، و Hopwood حيث أهميتها النسبية بقيمة قدرها (33\%) وهي نسبة تعتبر منخفضة جداً وذات دلالة واضحة فئرة

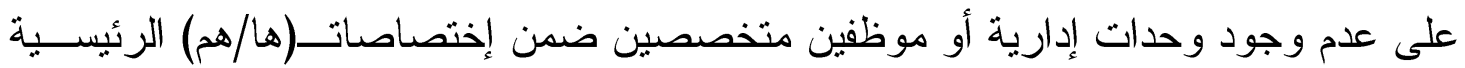

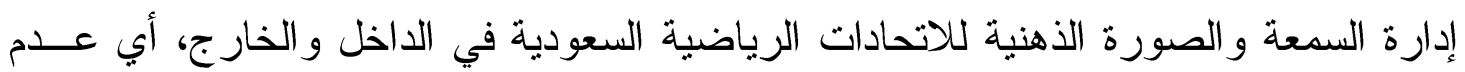
وجود وحدات إدارية أو موظفين مختصين للعلاقات العامة ضمن إختصاصاتــ(ها/هم) القيــام

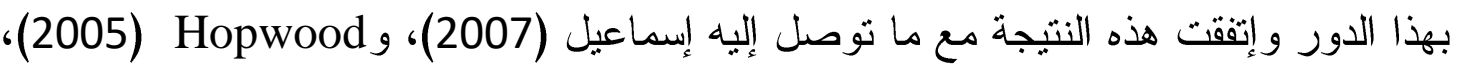

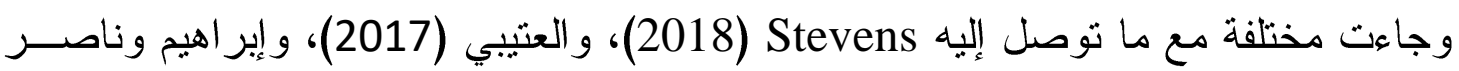

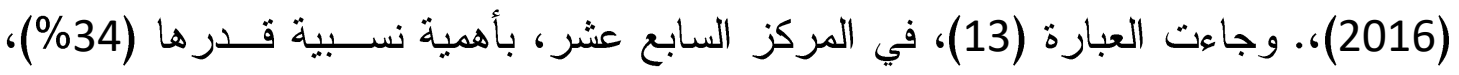

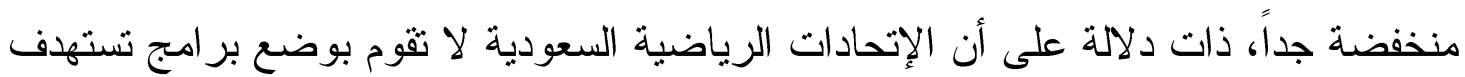

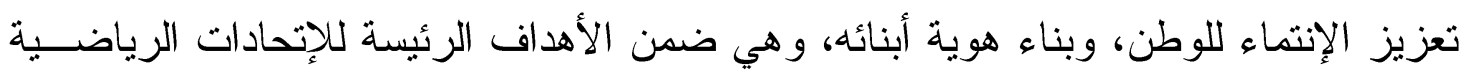

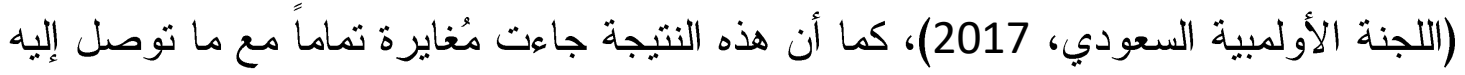
Çelebi

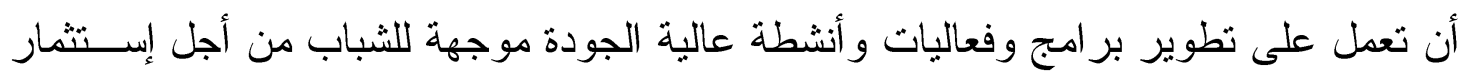

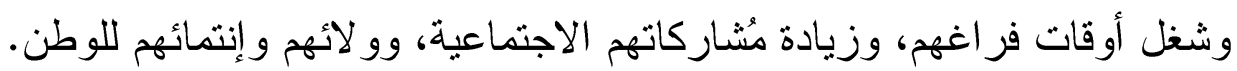

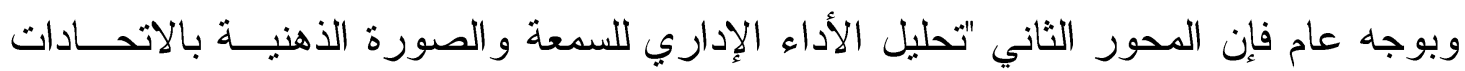

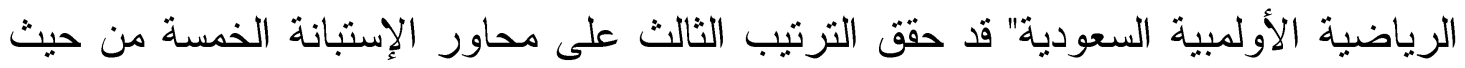

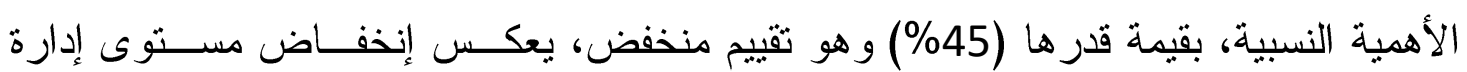
السمعة و الصورة الذهنية للإتحادات الرياضية السعودية في الداخل و الخارج.

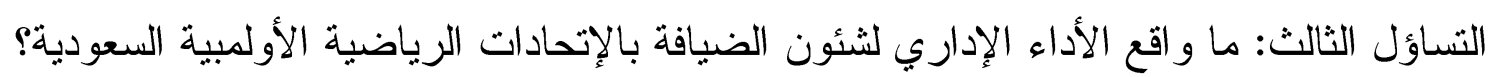

$$
\text { جدول (7) }
$$

تحليل الأداء الإداري لثشئون الضيافة بالإتحادات الرياضبة الأولمبية السعودية.

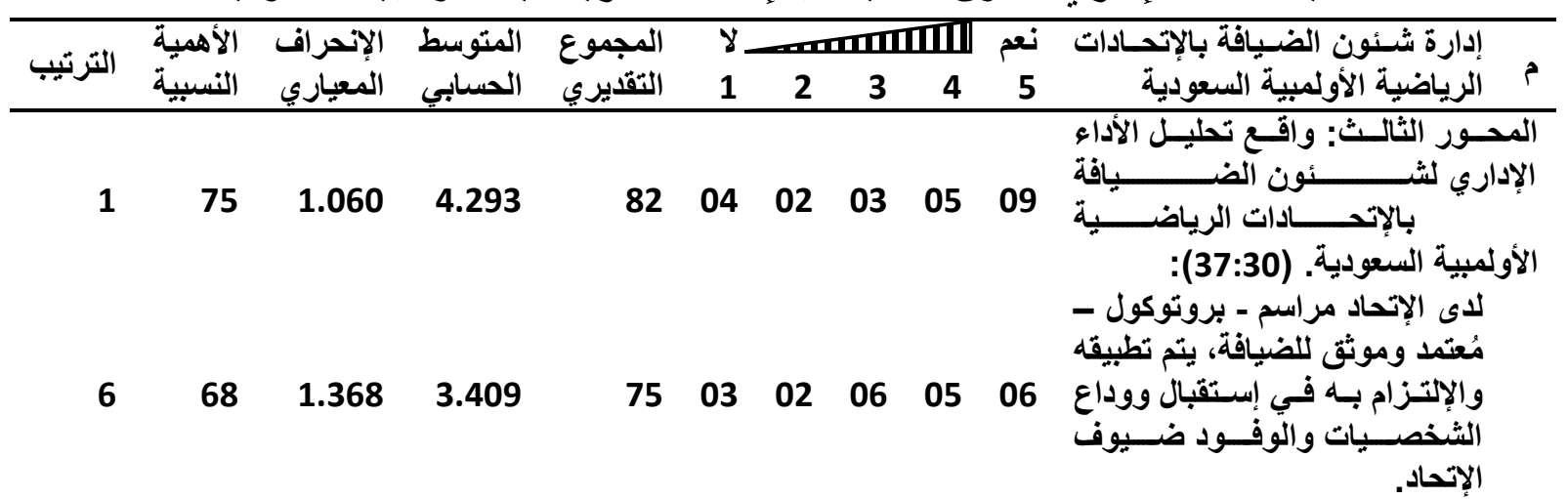

\section{6} المجلة العلمية لكلية التربية الرياضية للبنين بالهرم جامعة حلوان Web : jsbsh.journals.ekb.eg E-mail : sjournalpess@gmail.com 


\begin{tabular}{|c|c|c|c|c|c|c|c|c|c|c|}
\hline & & & & & & & & & & 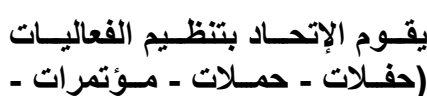 \\
\hline 5 & 83 & .889 & 4.136 & 91 & 00 & 01 & 04 & 08 & 09 & 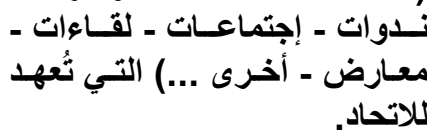 \\
\hline \multirow[t]{2}{*}{4} & 83 & 1.082 & 4.136 & 91 & 01 & 01 & 02 & 08 & 10 & 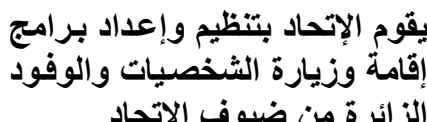 \\
\hline & & & & & & & & & & 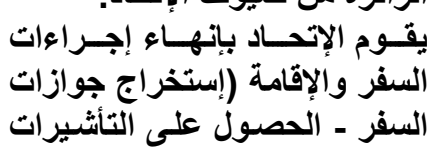 \\
\hline \multirow[t]{2}{*}{3} & 84 & 1.140 & 4.182 & 92 & 01 & 01 & 03 & 05 & 12 & 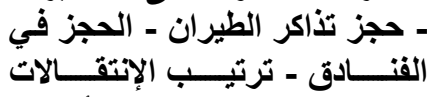 \\
\hline & & & & & & & & & & 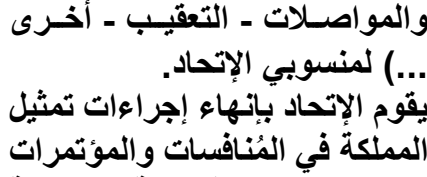 \\
\hline \multirow[t]{2}{*}{2} & 91 & .671 & 4.545 & 100 & 00 & 00 & 02 & 06 & 14 & 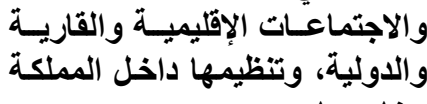 \\
\hline & & & & & & & & & & 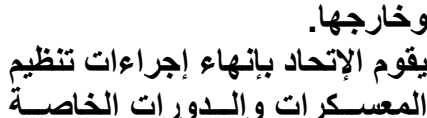 \\
\hline \multirow[t]{2}{*}{1} & 92 & .666 & 4.591 & 101 & 00 & 00 & 02 & 05 & 15 & المملكة أو خارجها. \\
\hline & & & & & & & & & & 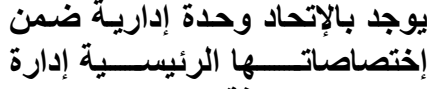 \\
\hline \multirow[t]{2}{*}{8} & 39 & 1.327 & 1.954 & 43 & 12 & 04 & 03 & 01 & 02 & Hospitality شـــون الضــيافة \\
\hline & & & & & & & & & & 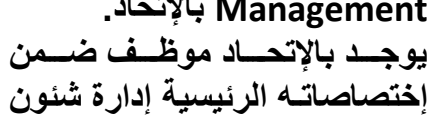 \\
\hline \multirow[t]{2}{*}{7} & 42 & 1.377 & 2.09 & 46 & 11 & 04 & 03 & 02 & 02 & Hospitality الضـــــيافة \\
\hline & & & & & & & & & & Manager بالآتحاد. \\
\hline
\end{tabular}

يتضح من جدول (7) أن العبارة (35) جاءت في الترتيب الأول بهذا المحور محققــة

أهمية نسبية قدر ها (92\%) وهي نسبة مرتفعة جداً، ذات دلالة على أن الإتحادات الرياضــبة تقوم بمسئولياتها الخاصة بإنهاء إجر اءات تتظيم المعسكر ات و الــدورات الخاصـــة بتطــــير الكو ادر و المنتخبات داخل المملكة أو خارجها. وجاءت العبارة (34)، في المركز الثاني مــن حيث الترتيب في المحور، بأهمية نسبية قدر ها (91\%) مرتفعة جداً، وذات دلالة علـى قيـام الإتحادات الرياضية بإنهاء إجر اءات تمثيل المملكة في المُنافسات و المؤتمر ات و الاجتماعــات الإقليمية و القارية و الدولية، وتتظيمها داخل المملكة وخارجها. وجاء العبارة (33) في الترتيب

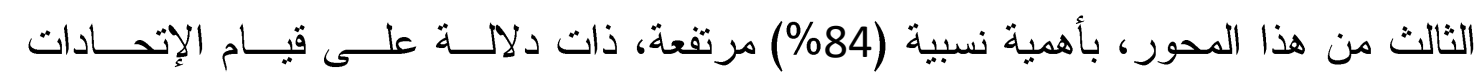

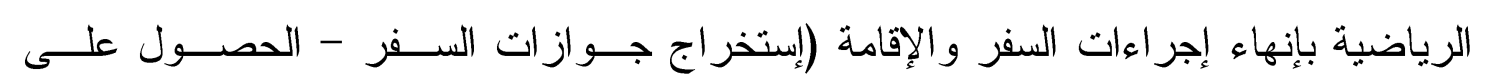

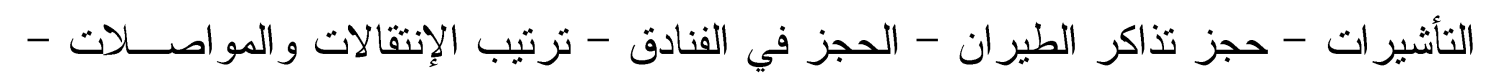
التعقيب - أخرى ...) لمنسوبيها. كما جاءت العبارة (36)، في المرتبة الأخيرة، بأهمية نسبية (39\%) منخفضة، ذات دلالة على عدم وجود وحدة إدارية ضمن إختصاصاتــــــا الرئيســة 
إدارة شئون الضيافة Hospitality Management بالإتحادات الرياضية متسقة في ذلك مع الحجرف (2020)، والعتيبي (2017)، والذي أكد على تدني مؤهلات ورواتب العاملين فـي لئي

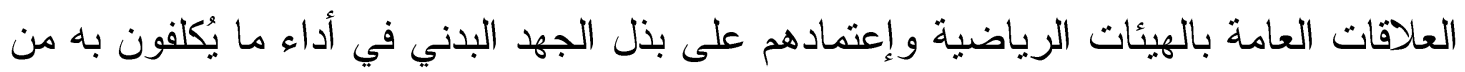

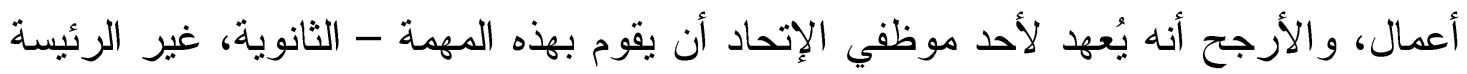

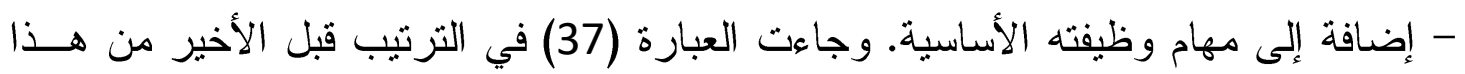

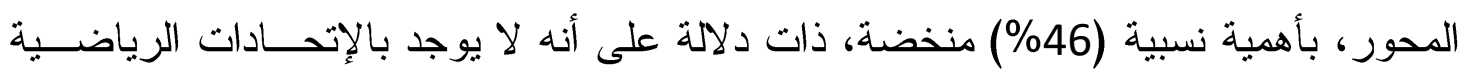

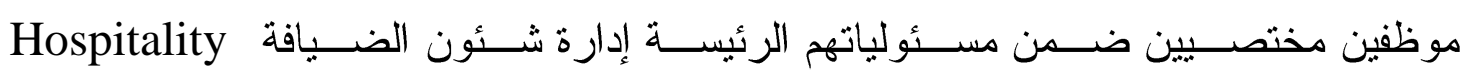

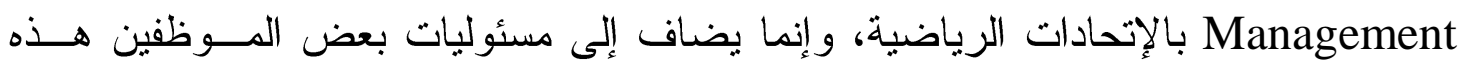
المهمة ولكن بصورة ضمنية، غير منصوص عليها في الوصف الوظيفي (حال وجوده) وهذا يتفق مع ما توصل إليه Wojciechowski (2017)، و هذا يعتبر تأكيد على نتيجــة العبـارة

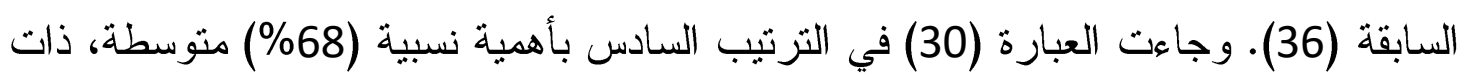

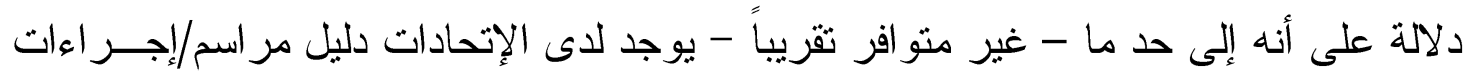

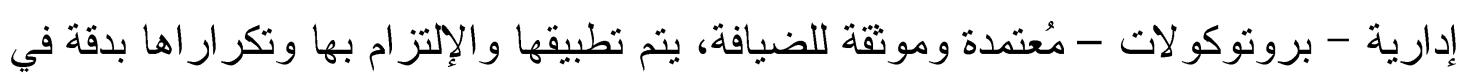

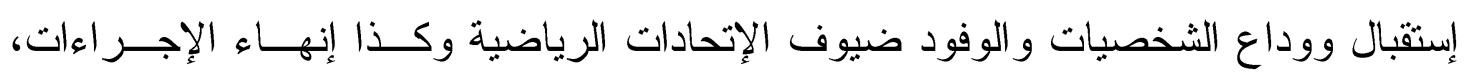

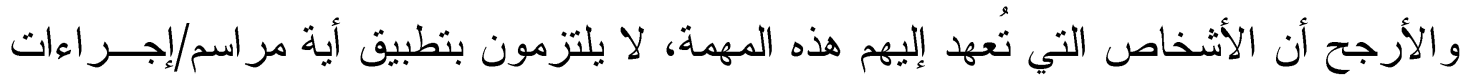

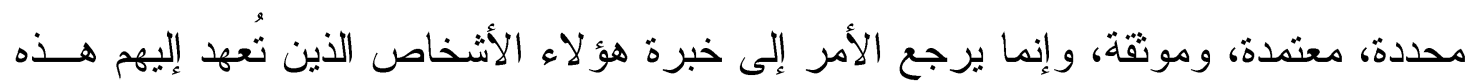

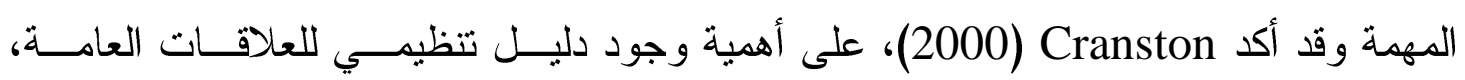

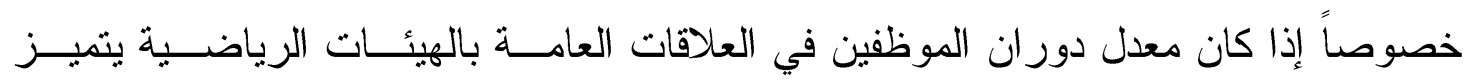

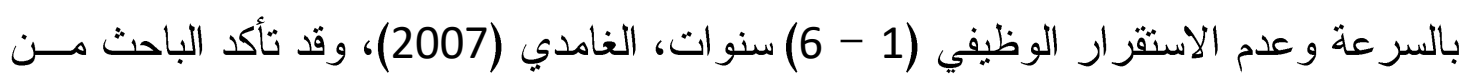

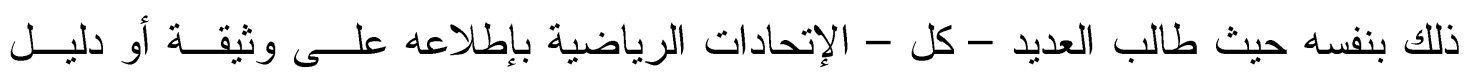

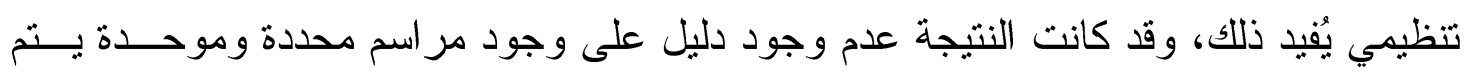
الإلتز ام بها من قبل القائمين على هذه المهمة وقد أكد على على ذلى ذلك.

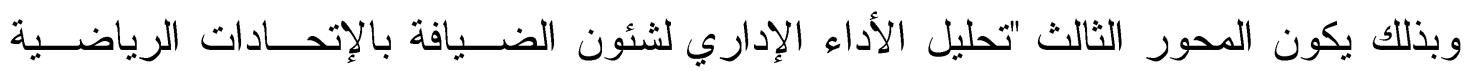

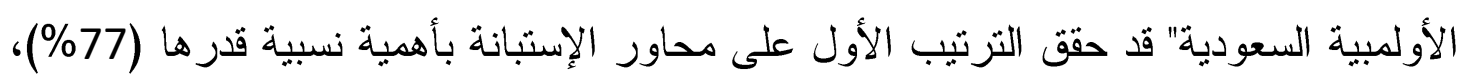

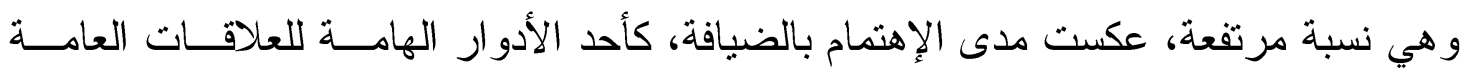

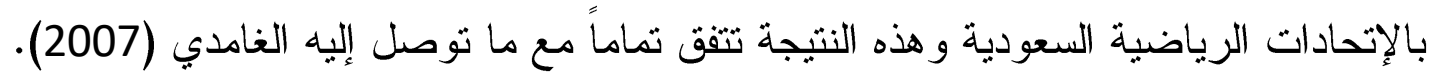

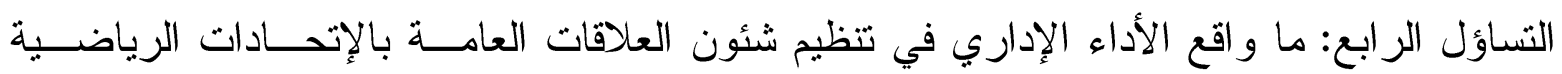
الأولمبية السعودية؟ 


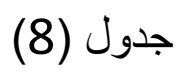

تحليل الأداء الإداري في تتظيم شُئون العلاقات العامة بالإتحادات الرياضية الأولمبية السعودية.

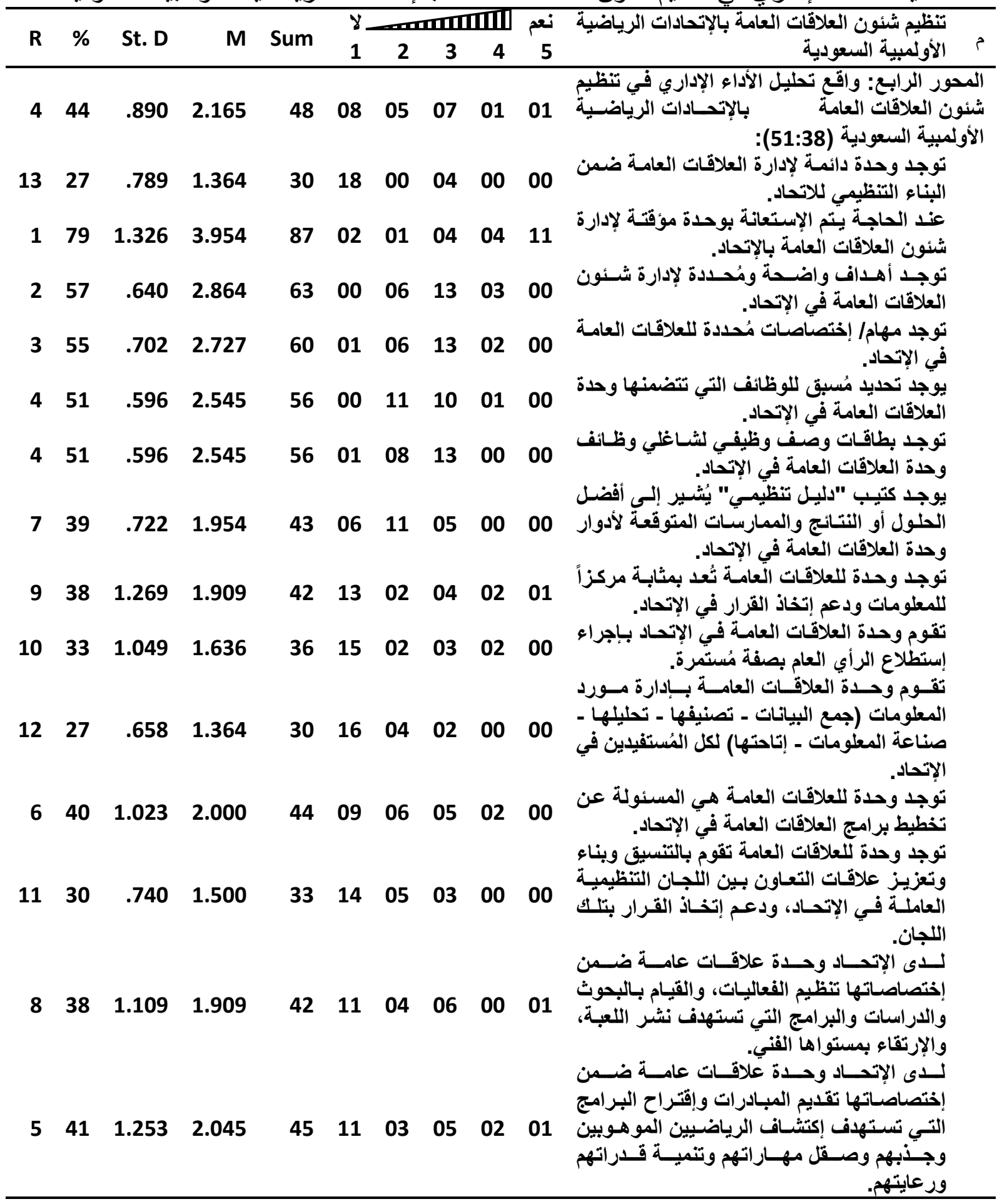

يتضح من جدول (8) أن العبارة (39) قد جاءت في التزتيب الأول من حيث الأهمية

النسبية بقيمة (79\%) مرتفعة، وهي ذات دلالة على أنه عند الحاجة ينم الإستعانة بوحدة إدارية

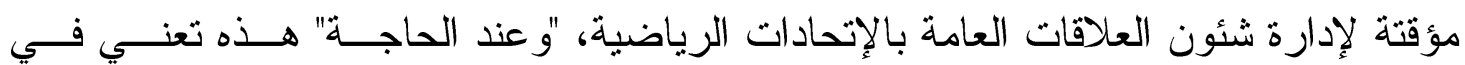

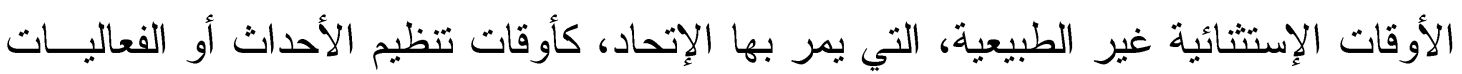


الرياضية الكبرى، أو أوقات الأزمات و هذا يتقق مع ما توصل إليه إبر اهيم وناصر (2016)،

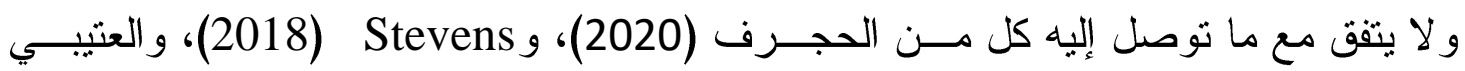
(2017)، ونستطيع القول بأنه كلما كبر حجم الهيئة الرياضية كلما زاد ذلك من إحتمال وجود

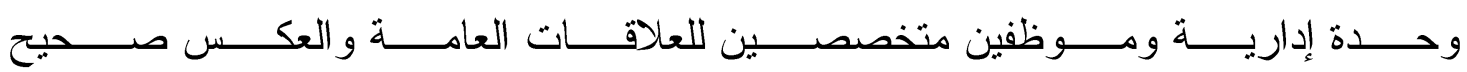
(2017،Wojciechowski)

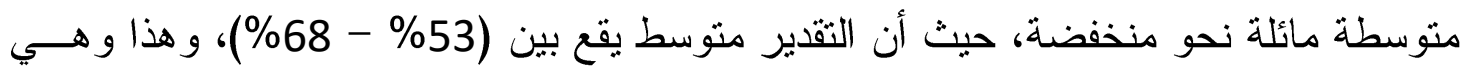

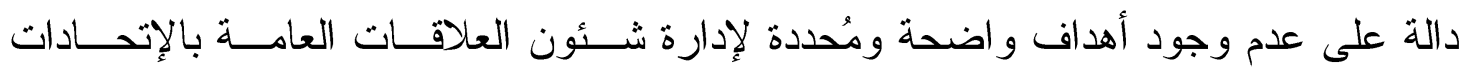

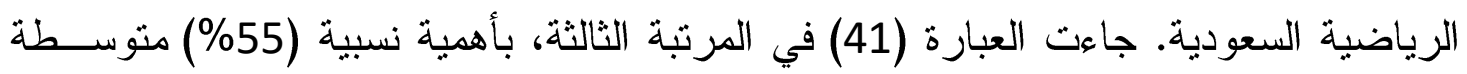

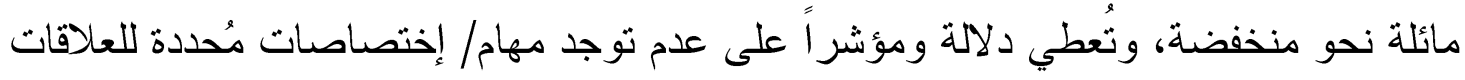

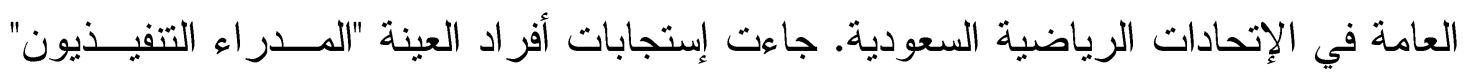

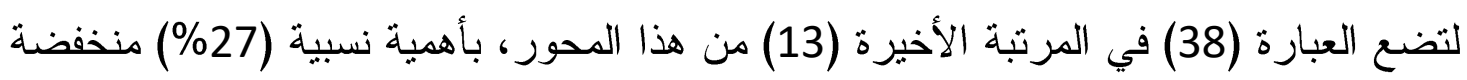

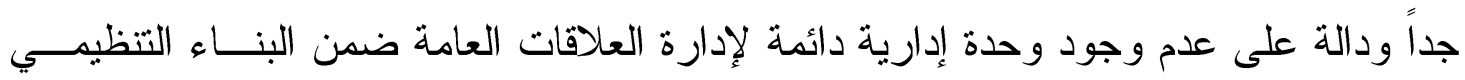

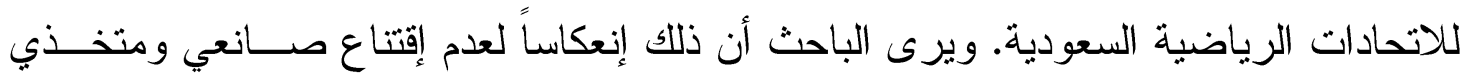

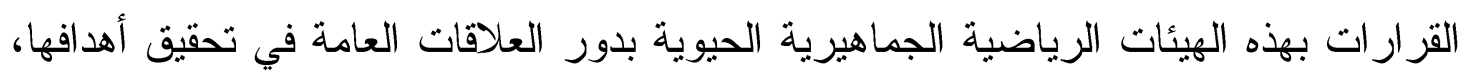
الأمر الذي تزتب عليه ضعف و إنخفاض القدرة على إدارة مورد المعلومات (جمع البيانات -

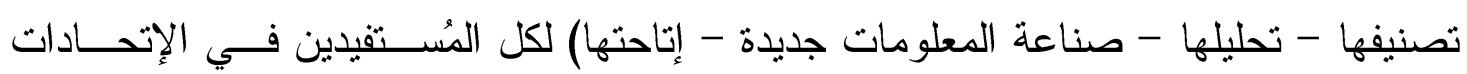

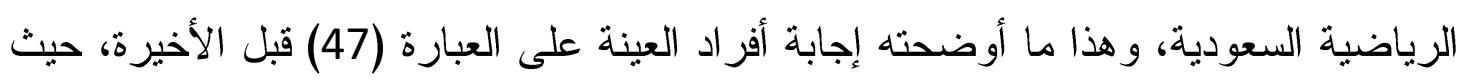

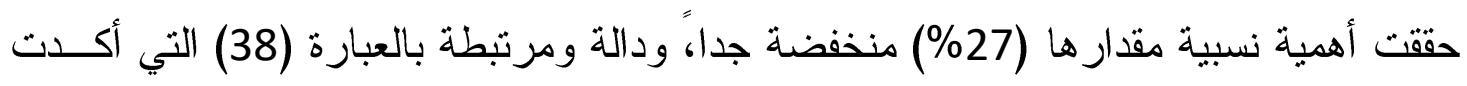

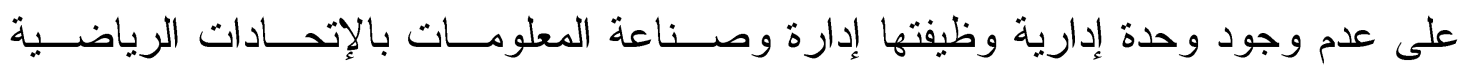

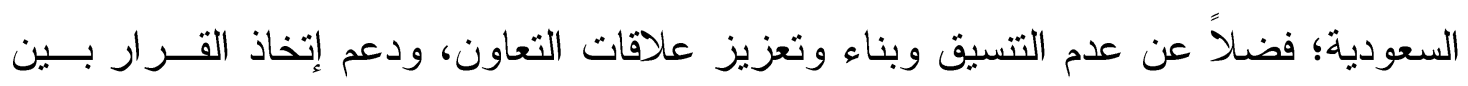

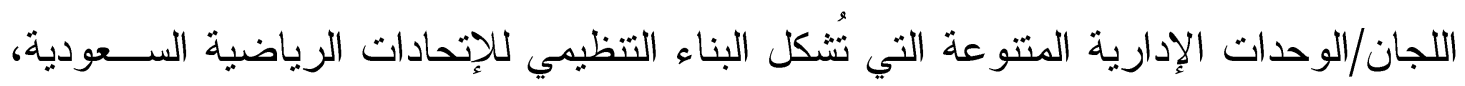

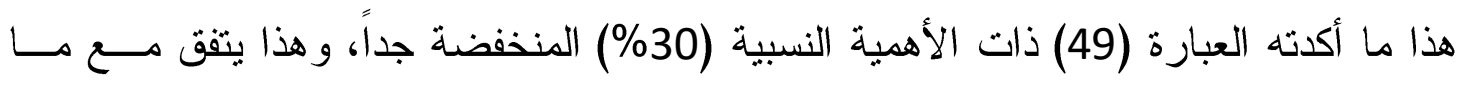

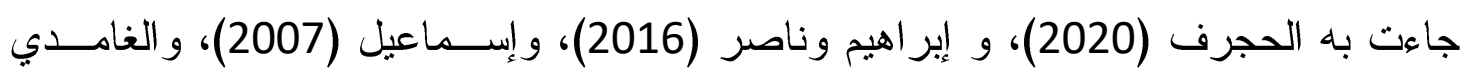

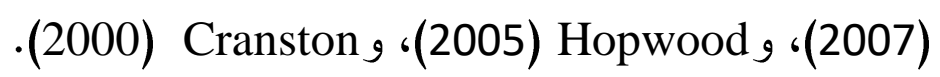

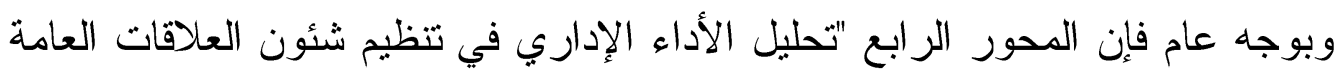

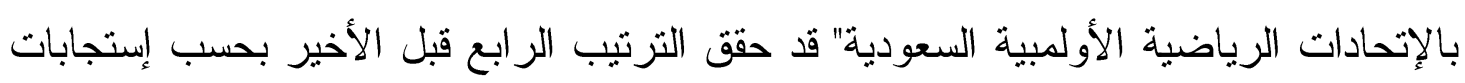

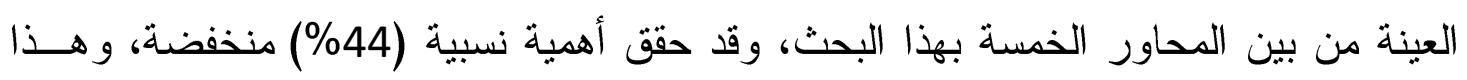

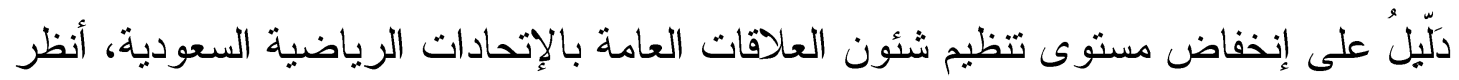

جدول (8).

التساؤل الخامس: ما واقع الأداء الإداري في تقويم أداء (أدوار) العلاقات العامة بالإتحادات الرياضية الأولمبية السعودية؟ 


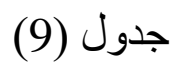

تحليل الأداء الإداري في تقويم أداء (أدوار) العلاقات العامة بالإتحادادات الرات الرياضية الأولمبية السعودية.

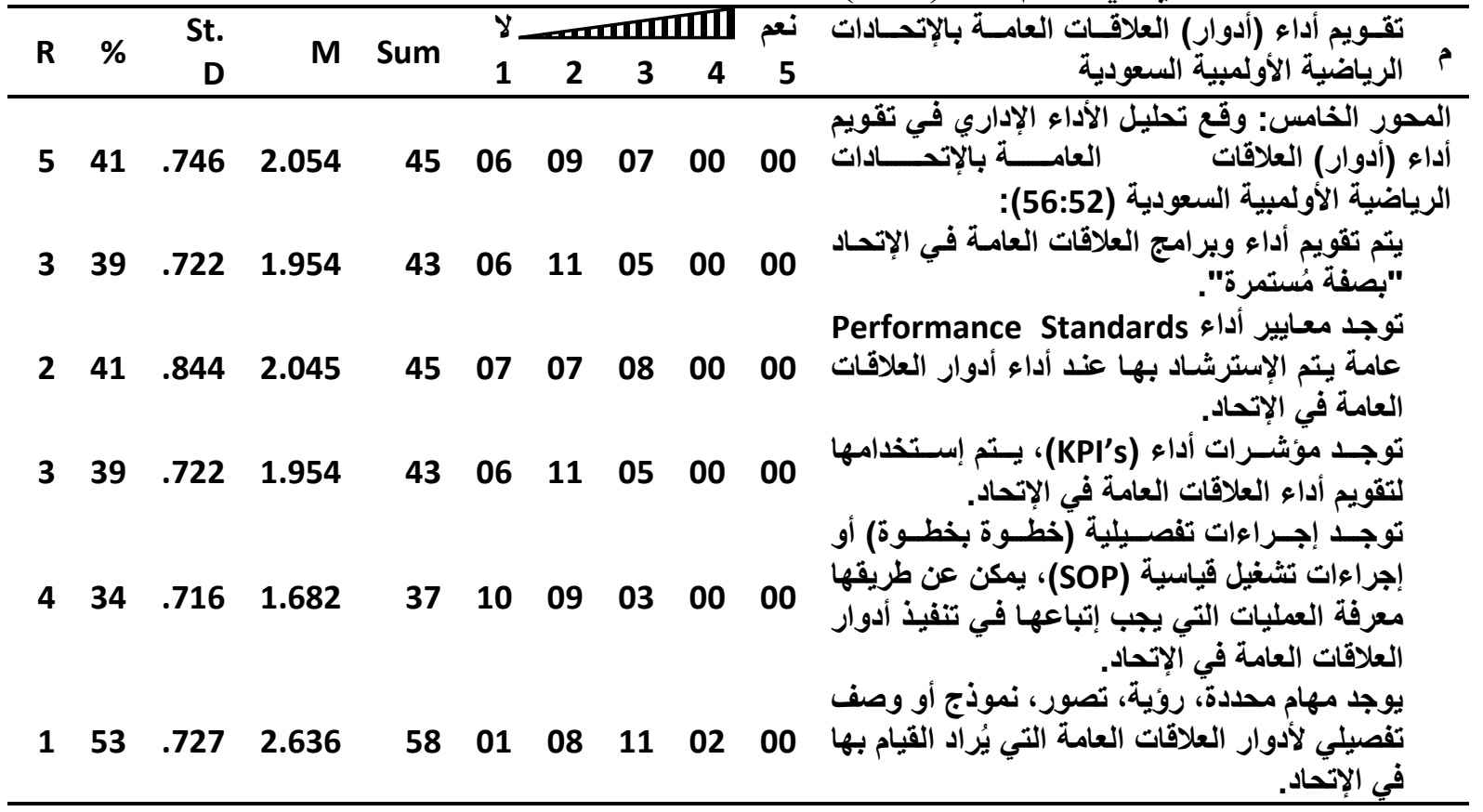

يتضح من جدول (9) حصول العبارة (56) على الترتيب الأول من حيــث الأهميــة

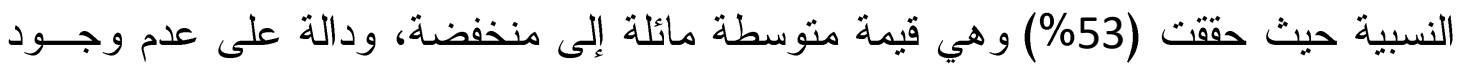

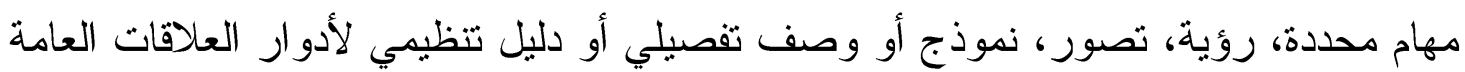
التي يُر اد القيام بها في الإتحادات الرياضية السعودية. جاءت العبارة (53) في المرتبة الثانيــة

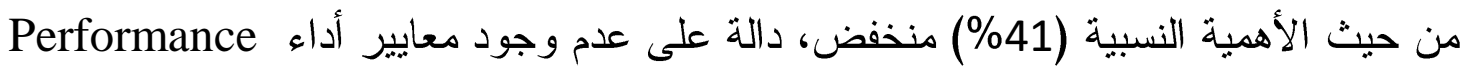

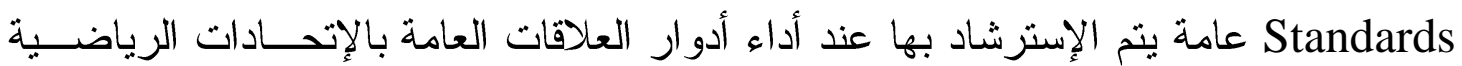
السعودية. وحققت العبارة (55) الترتيب الأخير على عبار ات المحور الخامس بأهمية نســبية

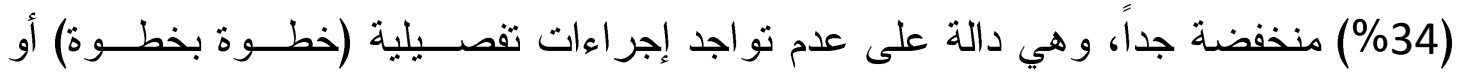
إجر اءات تشغيل قياسية (Standards Operating Procedures(SOP، يمكن عن طريقهـ معرفة العمليات التي يجب إتباعها في تتفيذ أدوار العلاقات العامــة بالإتحــادات الرياضــية

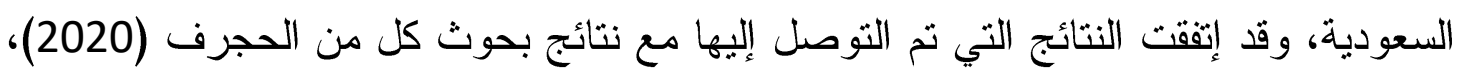

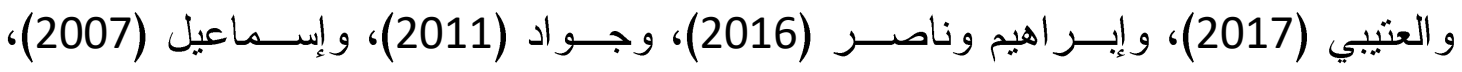

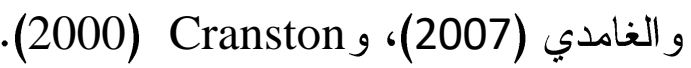
وبوجه عام فإن الدحور الخامس "تحليل الأداء الإداري في تقويم أداء (أدوار) العلاقات العامة

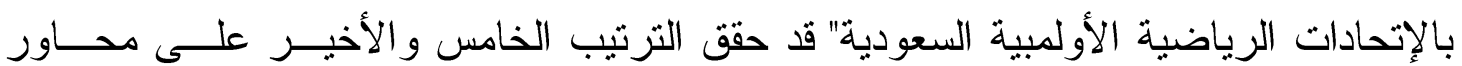

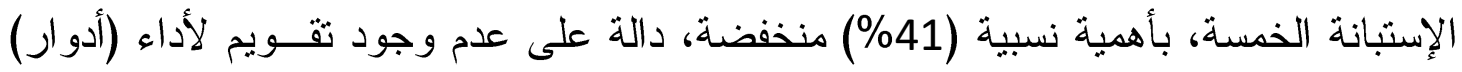
العلاقات العامة بالإتحادات الرياضية السعودية. 


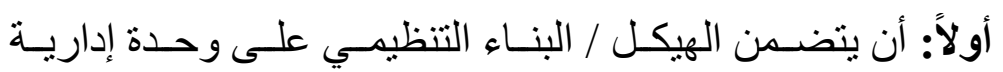

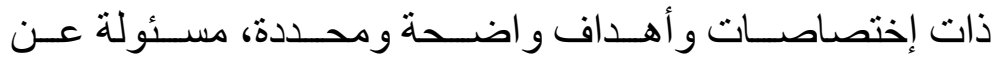

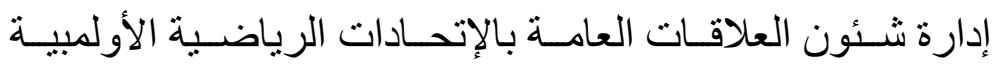

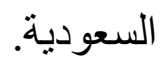

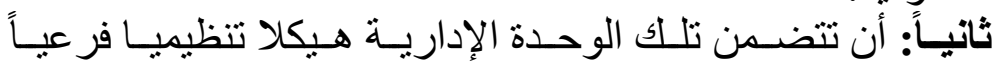

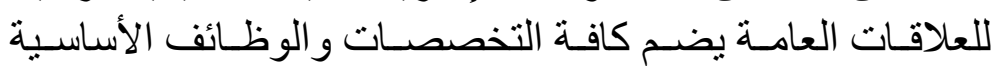

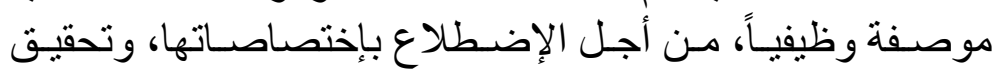
أهدافها.

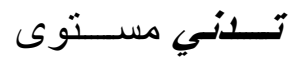

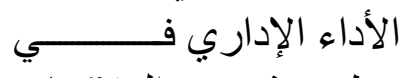

تنظـيم شـــئون العلاقــات الإن

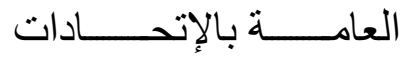

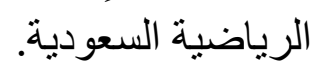

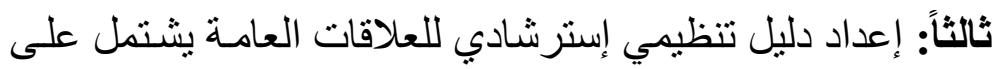

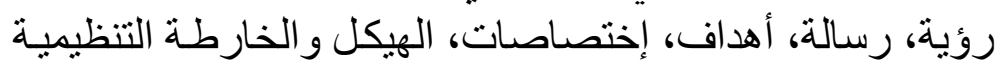
للوحدة ووظائفها، وصف مهام و إجر اءات الوحلة الوحة، ملاحق.

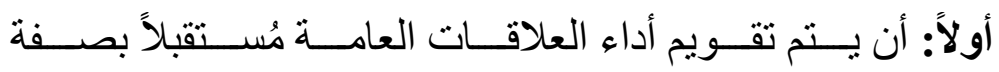

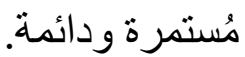

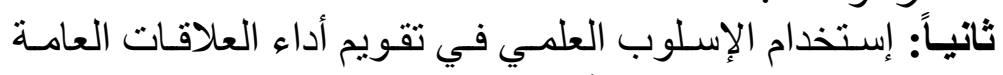

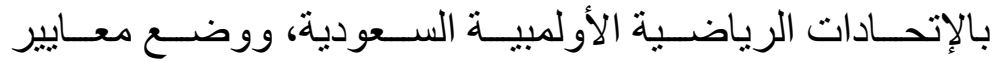

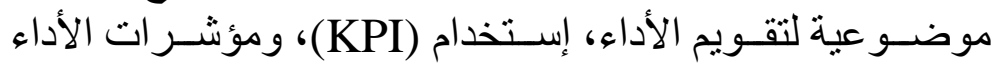

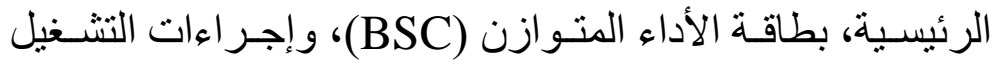

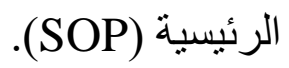

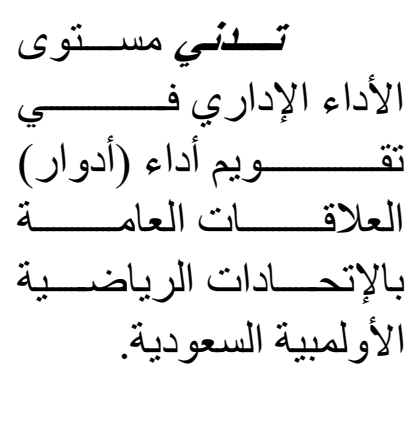

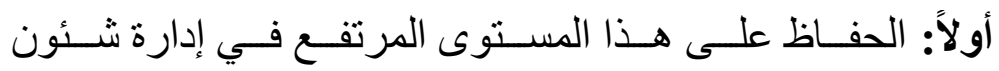

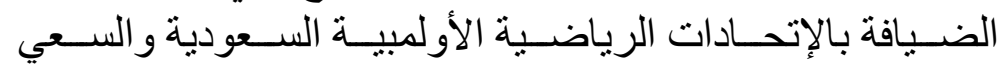
إلى تطويره.

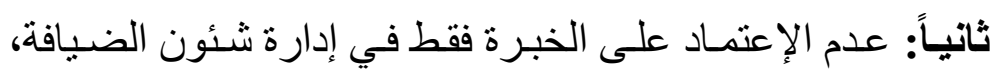

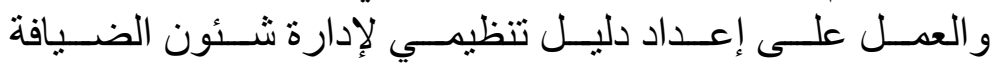

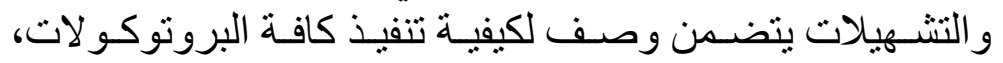

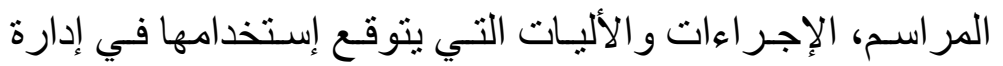
شئون الضيافة بالإتحادات الرياضية الأولمبية السعودية.

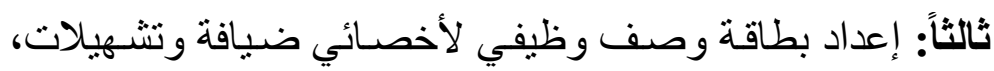

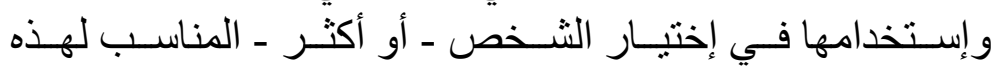

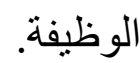

\section{3}

المجلة العلمية لكلية التربية الرياضية للبنين بالهرم جامعة حلوان Web : jsbsh.journals.ekb.eg

E-mail : sjournalpess@gmail.com 
1. إبر اهيم، قاسم وناصر، رهام. (2016). دور العلاقات العامة في المجال الرياضي مــن وجهة نظر العاملين فيها. بحث منشور ، مجلة جامعة تشرين للبحوث و الدراســات

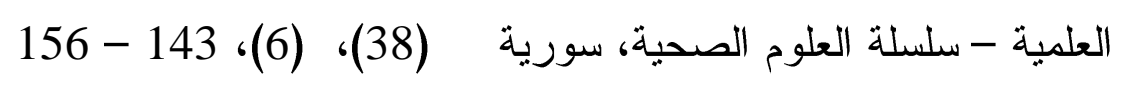

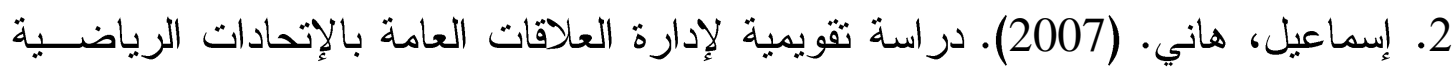

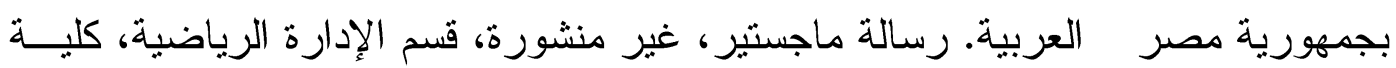

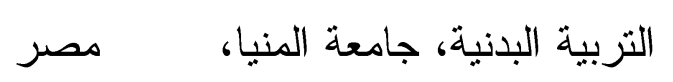

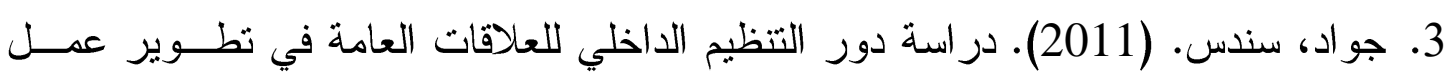

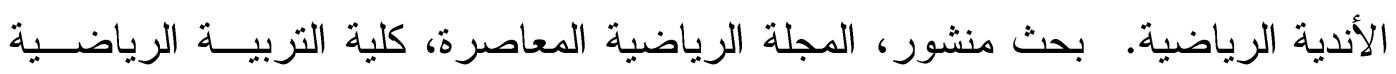

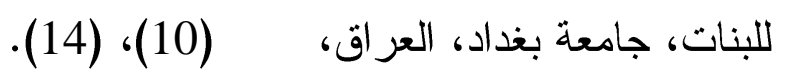

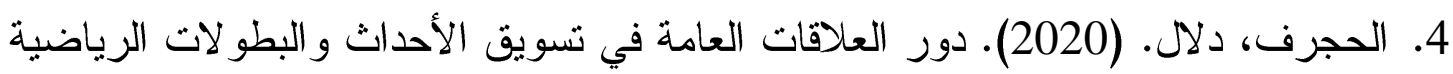

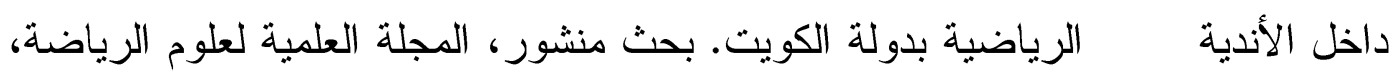

$$
\text { ، } 23 \text { - } 9 \text { (2) }
$$

https://journals.ekb.eg/article_149731_4a9ac4cd2ab3556aec73abd650 316.pdf f1e

5. العتيبي، عمر. (2017). العلاقات العامة ودورها في تحقيق أهداف الهيئة العامة للرياضة

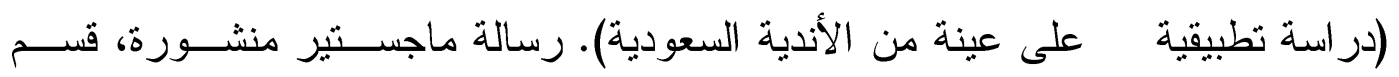
الإعلام، كلية العلوم الاجتماعية، جامعة أم القرى، السعودية.

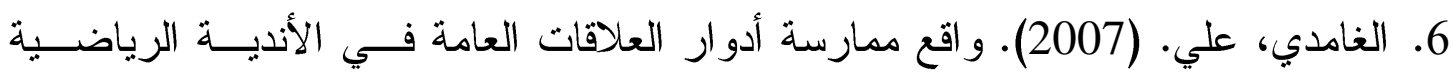

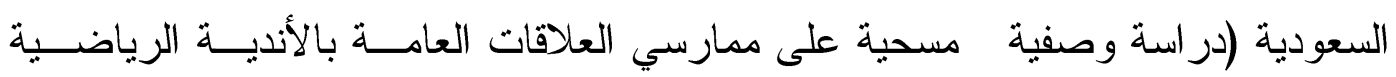
السعودية). قسم الإعلام، كلية الآداب، جامعة الملك سعود، السعودية.

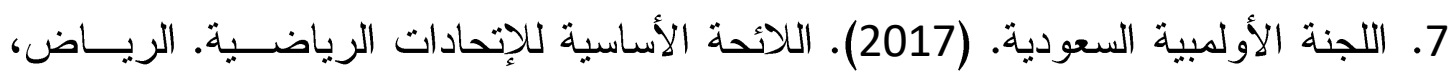
السعودية.

8. Anderson, W. B. (2006). American v. National Football League: Using public relations to "win" a war against a monopoly. Department of Communication, University of Scranton, USA Public Relations Review 32, 53-57,

file://C:/Users/aalgmmal/Downloads/1-s2.0-S0363811105001839main\%20(2).pdf

9. Boyle, R., \& Haynes, R. (2006). The football industry and public relations. In J. L'Etang \& M. Pieczka (Eds.), Public relations: Critical debates and contemporary practice, (pp. 221-239). 
New York: Routledge.

10.Broom, G. M., \& Sha, B. (2013). Cutlip \& Center's effective public relations. Harlow: Pearson Education.

11.Brown, A. K., \& Isaacson, E. T. (2017). Sport \& public relations. In A. C. Billings (Eds), Defining sport communication (pp. 326338). New York, United States: Taylor \& Francis.

12.Çelebi, E. (2021). The effect of organization-public relations on sports fan loyalty. Journal of Human Sciences, 18(1), 94- 103. doi:10.14687/jhs. v18i1.6080 file://C:/Users/aalgmmal/Downloads/6080Article\%20Text-24829-1-10- 20210327.pdf

13.Coombs, D. S., \& Osborne, A. (2012). A case study of Aston Villa Football Club. Journal of Public Relations Research, 24(3), 201-221. doi:10.1080/1062726X.2012.671985

14.Coombs, W. T., \& Holladay, S. J. (2010). PR strategy and application: Managing influence. Chichester, U.K.: WileyBlackwell.

15.Cranston, J. T. (2000). A guide to Effective Public Relations for the High School Athletic Director. (Master Thesis), Rowan University,

https://rdw.rowan.edu/cgi/viewcontent.cgi? article=2649\&co ntext=etd

16.Grunig, J. E. (2006). Furnishing the edifice: Ongoing research on public relations as a strategic management function. Journal of Public Relations Research, 18(2), doi:10.1207/s1532754xjprr1802_5

17.Hon, L.C. (1997). What have you done for me lately? Exploring effectiveness in public relations. Journal of Public Relations Research, 9, 1-30.

18.Hon, L.C. (1998). Demonstrating effectiveness in public relations: Goals, objectives and evaluation. Journal of Public Relations Research, 10, 103-135.

19.Hopwood, M. K. (2005 a). Applying the public relations function to the business of sport. International Journal of Sports Marketing \& Sponsorship. 6 (3), 30 - $\quad$ 44, DOI: 10.1108/IJSMS-06-032005-B006,

https://www.emerald.com/insight/content/doi/10.1108/IJSM S-06-03-2005- B006/full/pdf?title=applying-the-publicrelations-function-to-the-business- of-sport

20.Hopwood, M. K. (2005 b). Public relations practice in English county cricket. Corporate Communications: An International Journal, 10(3),

201-212. 
https://doi.org/10.1108/13563280510614465

21.Hopwood, M., Kitchin, P., \& Skinner, J. (2010). Sport public relations and communication. Burlington, Mass.: Butterworth-Heinemann.

22.Isaacson, T. (2010). Sports public relations. In R. L. Heath (Eds.), The SAGE handbook of public relations (pp. 599-609). Los Angeles: SAGE Publications.

23.L'Etang, J. (2006). Public relations and sport in promotional culture. Public Relations Review, 32(4), 386-394. https://doiorg.ezproxy.aut.ac.nz/10.1016/j.pubrev.2006.09.00 6

24.L'Etang, J. (2013). Sports public relations. Thousand Oaks, California: SAGE.

25.L'Etang, J. (2015). Critical perspectives in sports public relations. In Pedersen, $\mathrm{P}$ (Eds.), Routledge handbook of sport communication (pp. 503-511). London: Routledge.

26.L'Etang, J., \& Hopwood, M. (2008). Call for papers-public relations and sport. Public Relations Review, 34(3), 87-89. https://doi.org/10.1016/j.pubrev.2008.05.001

27.Limor, Y., Leshem, B., \& Mendelzis, L. (2013). Public relations strategy and tactics. Raanana, Israel: The Open University. (forthcoming).

28.Moore, J. H. (2011). Predictors of Strategic Influence Among College Sports Public Relations Directors in College Athletic Departments: The Impact of Managerial Orientation and Leadership Personality Trait, Skill, and Style. (Doctoral

Dissertation). School of Education, Colorado State University. https://mountainscholar.org/bitstream/handle/10217/70458/ Moore_colostate _0053A_10780.pdf?sequence $=1$

29.Mullin, B. J., Hardy, S., \& Sutton, W. A. (2014). Sport Marketing (4th ed.). Champaign, IL: Human Kinetics.

30.Pratt, A. N. (2013). Integrated impression management in athletics: A qualitative study of how NCAA Division I athletics directors understand public relations. International Journal of Sport Communication, 6(1), 42-65. Retrieved from https://journals.humankinetics.com/journal/ijsc

31.Şerbănică, D., \& Constantinescu, M. (2016). Using public relations in sports, Romanian Journal of Marketing https://www.researchgate.net/publication/305044397_Using public_relation s_in_sports

32.Stevens, p. (2018). Sport Public Relations in New Zealand: Analyzing the State of the Discipline in New Zealand National 
Sport Organizations. (Master thesis). School of Communication Studies, Faculty of Design and Creative Technologies. Auckland University of Technology. https://openrepository.aut.ac.nz/bitstream/handle/10292/1250 9/StevensP.pdf ?sequence $=3$

33.Stoldt, G.C. (2008). Interview with John Humenik, executive director of the College Sports Information Directors of America. International Journal of Sport Communication, 1(4), 458-464.

34.Stoldt, G. C., Dittmore, S. W., \& Branvold, S. E. (2006). Sport Public Relations. Champaign, IL: Human Kinetics.

35.Stoldt, G. C., Dittmore, S. W., \& Branvold, S. E. (2012). Sport public relations: Managing stakeholder communication. Champaign, IL.: Human Kinetics.

36.Stoldt G. C., Miller L. K., and Vermillion M. (2009). Public Relations Evaluation in Sport: Views from the Field. International Journal of Sport Communication, (2) 223-239. Human Kinetics, Inc.

37.Stoldt, G.C., \& Narasimhan, V. (2005). Self-assessments of collegiate sports information professionals regarding their public relations task expertise. International Journal of Sport Management, 6(3), 252-269.

38.Summers, J., \& Morgan, J. M. (2008). More than just the media: Considering the role of public relations in the creation of sporting celebrity and the management of fan expectations. Public Relations Review, 34(2), 176-182. doi:10.1016/j.pubrev.2008.03.014

39. Waters, D. R. (2013). Applying public relations theory to increase the understanding of sport communication in sports public relations. In Pedersen, P (Eds.), Routledge Handbook of Sport Communication (pp. 66- 74). New York: Routledge.

40.Wilcox, D.L., Cameron, G.T., Ault, P., \& Agee, W.K. (2007). Public relations: Strategies and tactics (8th ed.). Boston: Pearson. 41. Wojciechowski, T. (2017). Structures and Professionalization of Public Relations in National Sports Governing Bodies - a Comparison Between Austria and Germany. Conference Proceedings Trends in Business Communication 2016, Springer Gabler, DOI 10.1007/978-3-658-17254-1, 79-90, https://link.springer.com/content/pdf/10.1007\%2F978-3-65817254-1.pdf 


\section{ملخص البحث}

تحليل الأداء الإداري لبعض أدوار العلاقات العامة بالإتحادات الرياضية الأولمبية السعودية

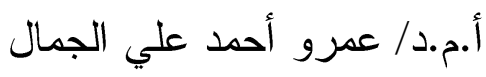

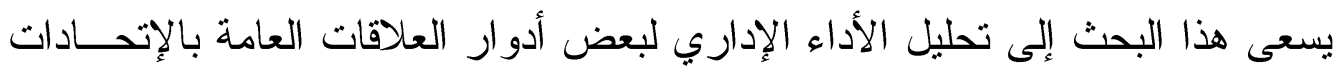

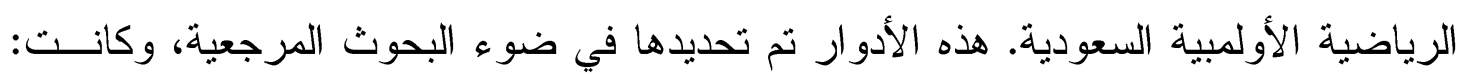

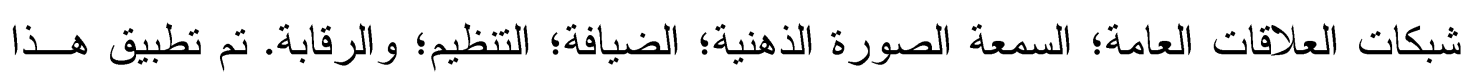

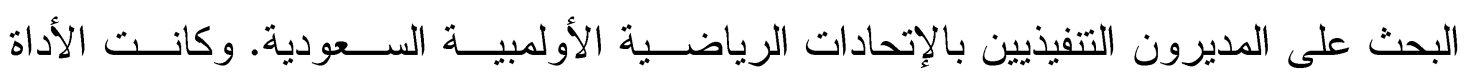

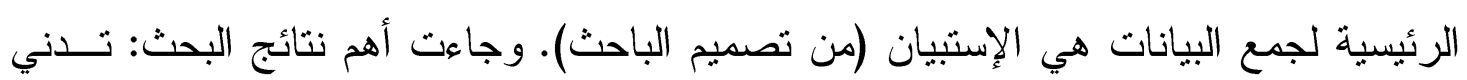

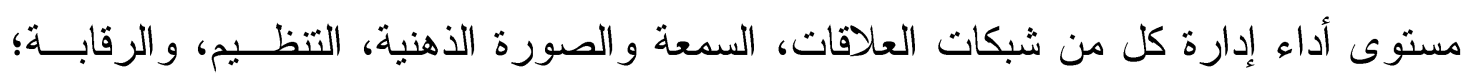

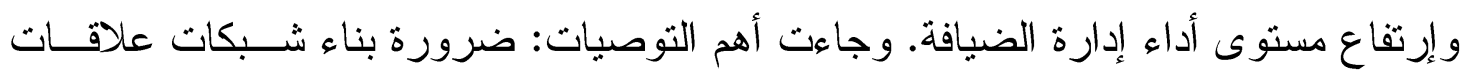

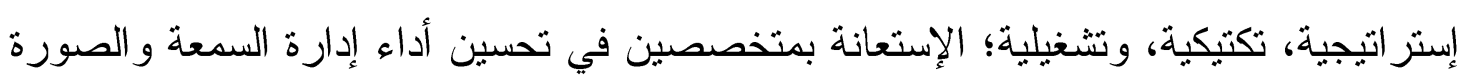

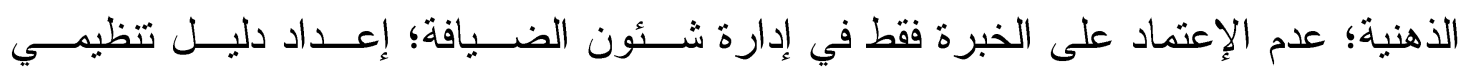
إسترشادي للعلاقات العامة؛ وتقويم أداء العلاقات العامة بإستخدام الأسلوب العلمئ إندي. 


\section{Abstract \\ Analysis of the administrative performance of some public relations roles in Saudi Olympic sports federations Asst Prof. Amr Ahmed Ali Mouhammed Algmmal}

This research seeks to investigate the administrative performance of some public relations roles in the Saudi Olympic sports federations. These roles were identified in the light of reference research, and they were: public relations networks; reputation, mental image; hospitality; organizing; and controlling. This research was applied to the CEO's of the Saudi Olympic sports federations. The main tool for data collection was the questionnaire (designed by the researcher). The most important results of the research were: the low level of management performance of each of the networks of relationships, reputation and mental image, organizing, and controlling, and The high level of performance of hospitality management. The most important recommendations were: the need to build networks of strategic, tactical, and operational relationships; Hiring specialists to improve the performance of reputation and image management; Not relying solely on experience in managing hospitality affairs; Preparing a guiding organizational manual for public relations; And evaluate the performance of public relations using the scientific method 